\title{
Substitution of Factors in the Cost Function of the Chemical Industry
}

\author{
Mansour Asgari ${ }^{1}$ \\ Tayyebeh Rahnenoon Piruj ${ }^{2}$ \\ Saedeh Hoshmandghahar ${ }^{3}$ \\ | m.asgari@itsr.ir \\ t.rahnemoon@itsr.ir \\ s.hooshmand@itsr.ir
}

Received: 04/03/2021 | Accepted: 11/08/2021

\begin{abstract}
The chemical industry has one of the largest production value chains, and the products of these industries are widely used as intermediate goods in other industries. In this paper, as regards cost function, Allen's elasticities and own elasticities, price elasticities, Morishima elasticities, energy elasticity, and scales of economics have been estimated in seven selected activities of the chemical industry using statistics and information 2002(2)-2018(1). The results show that the average share of employment, wages, output, and energy of the chemical industry in the entire industrial sector are equal to 6.38 , $8.41,13.28$, and $17.45 \%$ percentages, respectively (in the period under review). In manufacturing of fertilizers and nitrogen compounds, plastics and synthetic rubber in primary forms, man-made fibers, soap and detergents, cleaning and polishing preparations, perfumes, and also cosmetic preparations, changes in energy input prices affect production costs more in comparison with changes in the prices of other inputs. In all seven selected activities, capital stock demand is more sensitive to changes in its price than other input. In addition, the amount of crossdemand hedges are mostly small. In manufacturing of basic chemicals, fertilizers and nitrogen compounds, paints, varnishes, and similar coatings, printing ink, mastics, and man-made fibers, the price elasticity of natural gas is higher than other types of energy. In the manufacturing of other chemical products, soap and detergents, cleaning and polishing preparations, perfumes, and cosmetic preparations, and plastics and synthetic rubber in primary forms, the price elasticity of electricity is higher than other inputs. Furthermore, the selected activities in this study have increasing returns to scale, thus the larger units of which are preferable to the smaller units.
\end{abstract}

Keywords: Chemical Industry, Cost, Translog, Allen Elasticity, Morishima Elasticity.

JEL Classification: D11, D24, D33.

1. Assistant Professor of Econmics, The Institute for Trade Studies and Research (ITSR), Tehran, Iran (Corresponding Author).

2. Ph.D. Student in Economics, Razi University and Researcher of the Institute for Trade Studies and Research (ITSR), Tehran, Iran.

3. Researcher of the Institute for Trade Studies and Research (ITSR), Tehran, Iran. 


\section{جانشينى عوامل در تابع هزينه صنايع شيميايى'}

m.asgari@itsr.ir

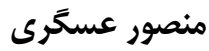

دانشيار موسسه مطالعات و يزوهش هاى بازر گانى، تهران، ايران (نويسنده مسئول). t.rahnemoon@itsr.ir

طيبه رهنمونييروج

دانشجوى دكترى اقتصاد، دانشگاه رازى كرمانشاه و يزوهشكر موسسه مطالعات و يروهشهاى بازر كانى، تهران، ايران.

s.hooshmand@itsr.ir

سعيده هوشمند

مقاله بزوهشى

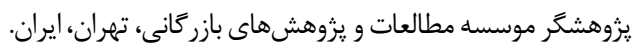

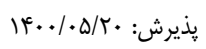

دريافت:

קُ مخيده: صنايع شيميايى دارنده يكى از بزرگترين زنجيرههاى ارزش توليد در ميان صنايع

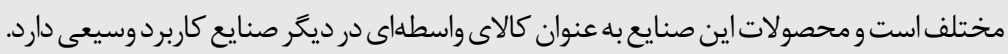

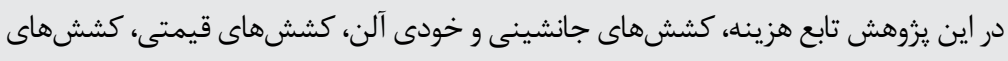

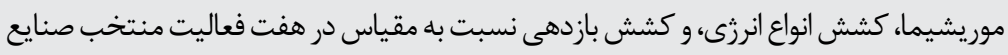

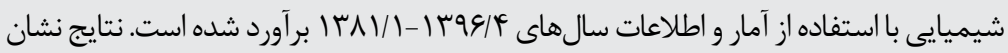

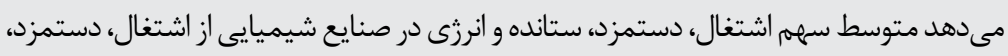

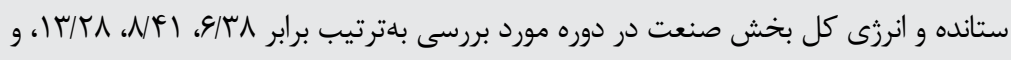

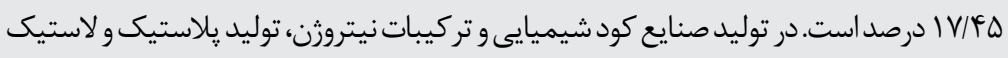

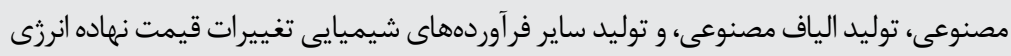

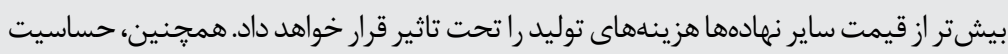

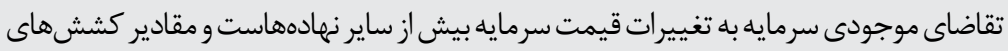

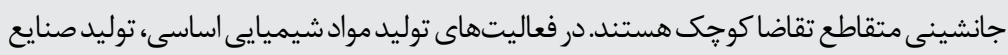

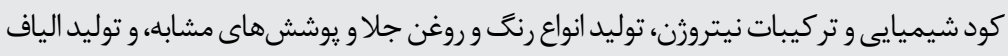

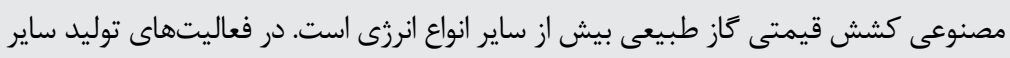

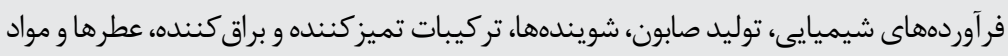

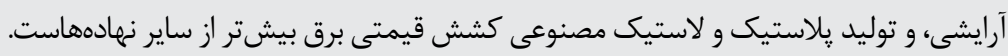

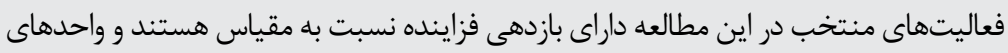

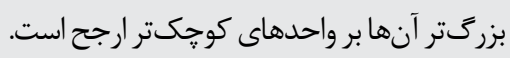

كليدوازهها: صنايع شيميايى، هزينه، ترانسلوگ، كششهاى آلن، كششهاى موريشيما طبقهبندى D33, D24, D11 :JEL.

ا. اين يُزوهش بركرفته از طرح يروهشى با عنوان لاطراحى الگوى كلانسنجى بخشهاى صنعت،

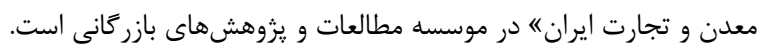


هزينه و سهرم هر يك از عوامل توليد، نقش بسيار مهمى در ادامه فعاليت و بقاى هر صنعت توليدى

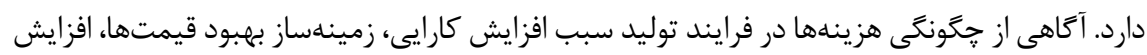
توان رقابتى، افزايش سطح رفاه اجتماعى، و پايدارى رشد اقتصادى خواهد شد. از طرفى، نقش صنعت

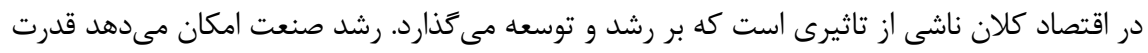
نيروهاى توليدى مدام در حال افزايش باشد و اين افزايش با توجه به توسعه روزافزون علم و فناورى

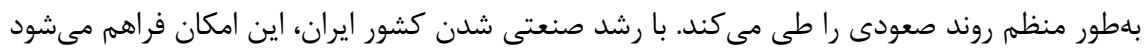
كه نيازهاى جامعه بيشتر تامين شود و توليد و وضعيت اجتماعى ارتقا يابد. فرايند توليد صنعتى كه رهي

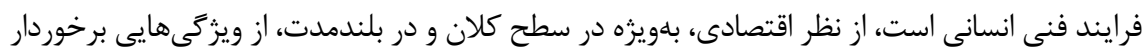
بوده كه تحت عنوان نقش صنعت در رشد و توسعه اقتصادى مورد بحث اقتصاددانان و انديشمندان مختلف قرار گرفته است. از سوى ديكر، شناخت كافى از وضعيت عملكرد بخش صنعت، سياستخذار را در

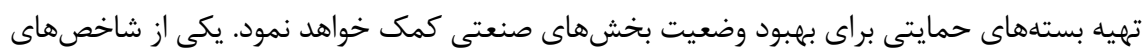

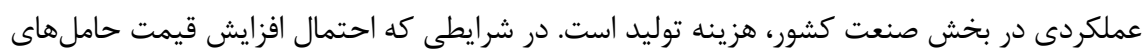

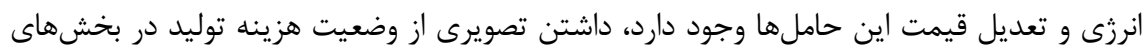
مختلف صنعتى، بهويزه بخش توليد صنايع شيميايى، مىتواند به عنوان يك مولفه در كنار ساير مولفهها،

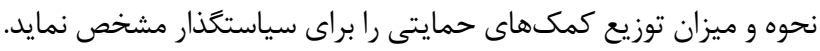

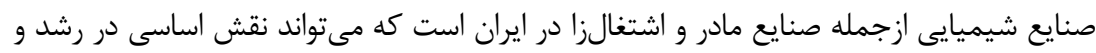

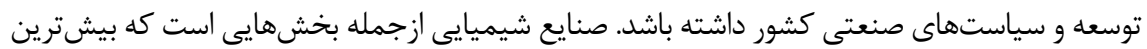

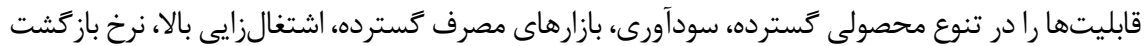

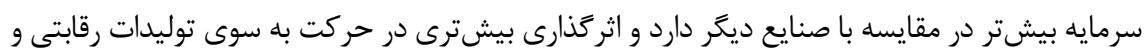
صادرات

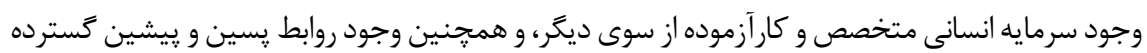
اين صنعت با صنايع ديكر مىتوان اين صنعت را به عنوان بيشران صنايع كشور مورد توجه ويزه قرار داد.

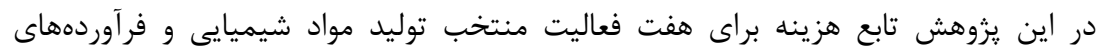

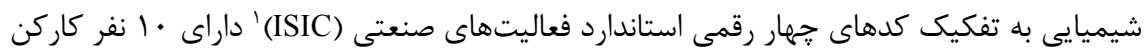




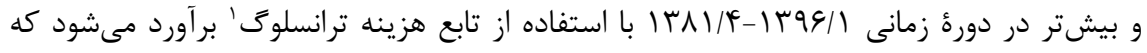

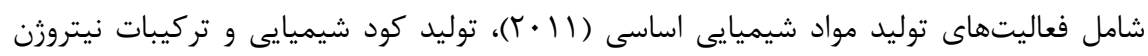

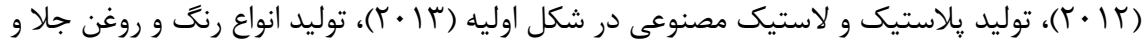

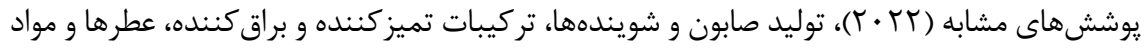

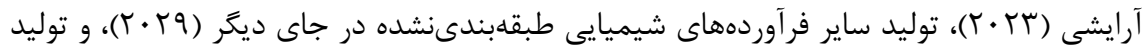

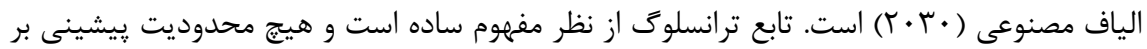
كششهاى جايكزينى ايجاد نمى كند، از اينرو در تجزيهوتحليل تجربى از آن استفاده كسترده ميىشود.

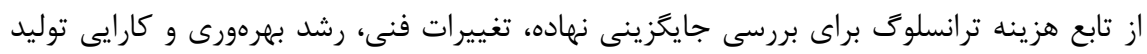

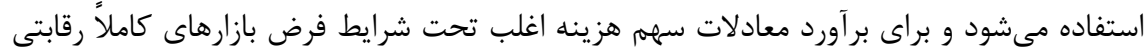
نهاده و ستاده مورد استفاده قرار مى كيرد. در اين يزوهش، رفتار هزينه صنايع شيميايى به تفكيك كدهاى جهار رقمى در قالب مدل و

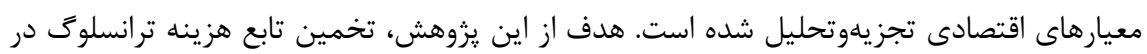
بخش صنايع شيميايى ايران است. يزوهش حاضر در راستاى دستيابى به هدف خود به دنبال ياسخى براى اين يرسشهاست: ا. آيا جانشينى بين عوامل توليد در صنايع شيميايى ايران وجود دارد؟ ؟.

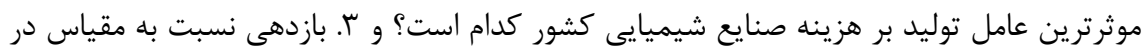

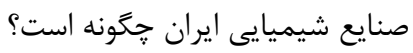
براى پاسخ به اين يرسشها از تابع هزينه ترانسلوگ استفاده مى تردد و در ادامه با استفاده از

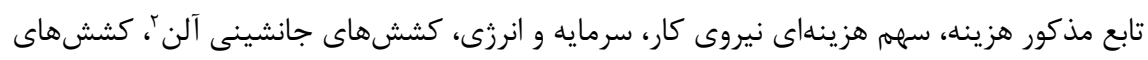
قيمتى تقاضا، كششهاى جانشينى موريشيما"، و نوع ارتباط جانشينى و مكملى عوامل توليد (نيروى هرى

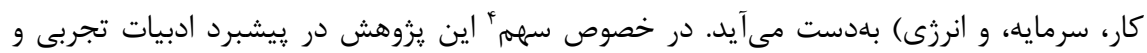
كاربرد مبانى نظرى در بخش صنعت و صنايع شيميايى كشور بايد كفت كه شكافهايى در استفاده از دادههاى فصلى در بخش صنعت و صنايع شيميايى، استفاده از آمار و اطلاعات صنايع شيميايى

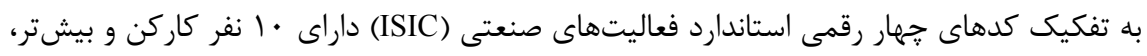

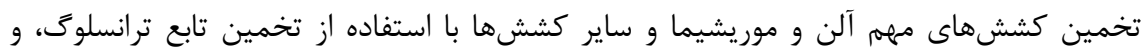

1. Translog Cost Function

2. Allen Substitution Elasticity 
محاسبه كشش انواع انرزى در هزينه صنايع شيميايى كشور وجود دارد كه يروهش حاضر با استفاده

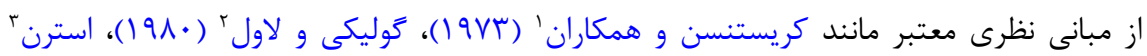

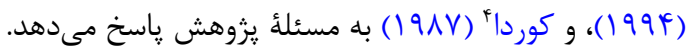

\section{مبانى نظرى بزوهش}

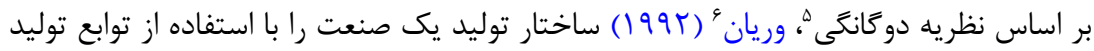
و هزينه مورد مطالعه قرار مىدهد. از طرفى، هر تابع توليد حداكثر داراى يك تابع هزينه حداقل به

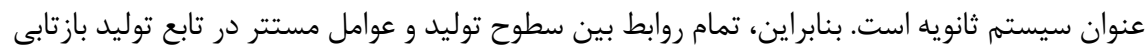
در تابع هزينه دارد. با اين اوصاف، استفاده از تابع هزينه داراى جندين مزيت است كه عبارتاند ازئ ا. در تابع هزينه، ضرورتى ندارد كه فرض شود تابع توليد نسبت به عوامل، همكن از درجه يك است،

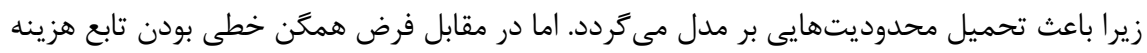

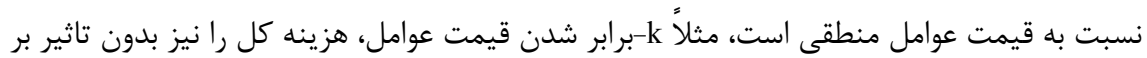
نسبت عوامل k-برابر مى كند و همين فرض همكن خطى بودن تابع هزينه نسبت به قيمت عوامل براى مئى

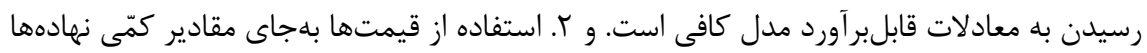
برترى دارد، زيرا در تابع هزينه، ميزان هزينه تابعى از قيمت نهادههاست و احتمال بروز همات همخطى مئى ميان

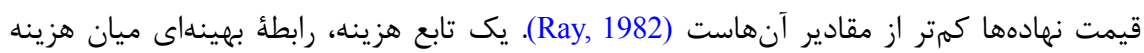

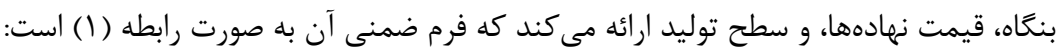
$\mathrm{C}=\mathrm{C}\left(\mathrm{P}_{1}, \mathrm{P}_{2}, \mathrm{P}_{3}, \ldots, \mathrm{P}_{\mathrm{i}}, \mathrm{Q}\right)$

$\mathrm{Q}=\mathrm{Q}\left(\mathrm{X}_{1}, \mathrm{X}_{2}, \ldots, \mathrm{X}_{\mathrm{n}}\right)$

كه در آن C هزينه كل توليد، Pيمت هر واحد نهاده i-ام بكار فتته در توليد، مقدار محصول توليدى، و X مقدار عوامل توليد است. بنابراين، تابع هزينه به صورت رابطه (r) ارائه مىشود: $\mathrm{C}(\mathrm{P}, \mathrm{Q})=\operatorname{Min} \mathrm{P} . \mathrm{X}$

$\mathrm{H}(\mathrm{X}) \geq \mathrm{Q}$

1. Christensen et al.

2. Guilkey \& Lovell

3. Stern

4. Kuroda

5. Dual

6. Varian 
براى بلددست آوردن تابع هزينه لازم است بودجه بنحاه با توجه به محدوديت فناورى كمينه \}= حداقل \{

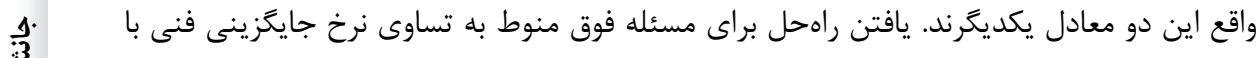
منفى نسبت قيمت نهادههاى توليدى است. تابع هزينه را مىتوان با شيوههاى كمينه كردن رابطه هزينه بهدست آورد. همجنين، با مفروض بودن تابع هزينه، مىتوان تابع توليد و فناورى توليدى را كه

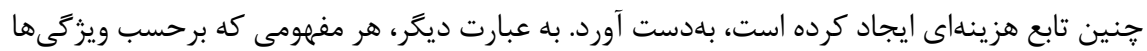

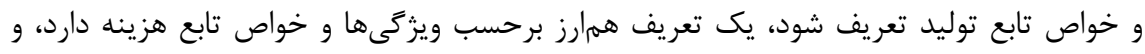

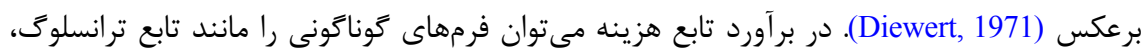
لئونتيف'، و درجه دوم بكار برد.

با توجه به اينكه تابع هزينه ترانسلوگ، ساختار توليد را محدود به هموتتيك؟ بودن و همخنى نمى كند و هيج محدوديتى روى كششهاى جانشينى نهادهاى توليد ندارد، لازم است اين هرين

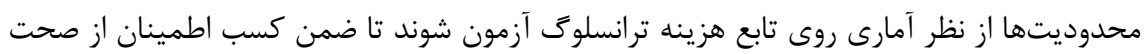

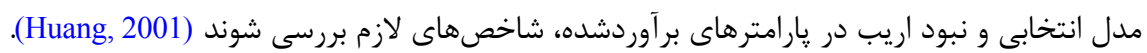
فرضيه هموتتيك بودن تابع توليد: هموتتيك نبودن به اين معناست كه تغيير مقياس توليد در نسبت يا سمهم استفاده از عوامل توليد، اريبدار خواهد شد، يعنى با تغيير مقياس توليد، نسبت

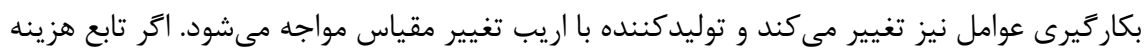

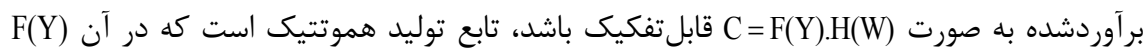
تابعى پيوسته و غيرنزولى از Y است كه به آن تابع هزينه هر واحد گويند. H(W) يكى تابع غيرمنفى، همكَن خطى، غيرنزولى، و مقعر نسبت به قيمت عوامل است (Lopez, 1980)، كه اين فرض محدوديت

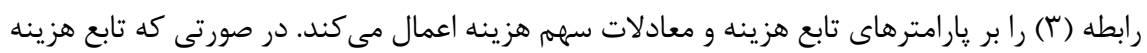
هيج گَنه اريب در ييشرفت فناورى نسبت به هيجكدام از عوامل توليد نداشته باشد، تابع هزينه بايد شرايط (r) را تامين نمايد:

$\mathrm{b}_{\mathrm{it}}=0, \quad \mathrm{i}=\mathrm{K}, \mathrm{L}, \mathrm{E}$

در صورت لزوم آزمون اين كه فناورى توليد، هموتتيك باشد و هيجگَنه اريبى در ييشرفت فناورى نباشد، محدوديتهاى خطى بايد آزمون شوند. در رابطه (با)، اگر تمام يارامترهاى i=K, L, E 
تفاوت معنادارى از صفر نداشته باشند، فناورى توليد هموتتيك' است و اثر تغيير مقياس بر استفاده از نهادهها اريب دارد (Gervais et al., 2006). براى اندازهيرى اين اريب برحسب يارامترهاى تابع هزينه $\mathrm{N}_{\mathrm{i}}=\frac{\partial \operatorname{Ln} S_{i}}{\partial \operatorname{Ln} Q}=\frac{\partial S_{i}}{\partial \operatorname{Ln} Q} \times \frac{1}{S_{i}}=\beta_{i Q} \times \frac{1}{S_{i}}$ ترانسلوى از رابطه (F) استفاده مى شود:

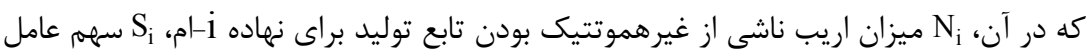

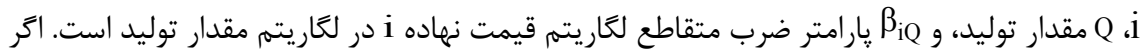

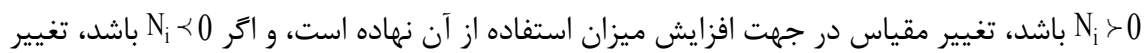

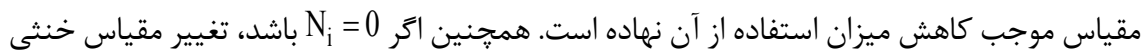

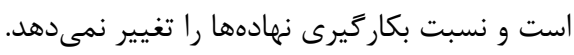

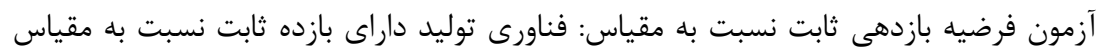

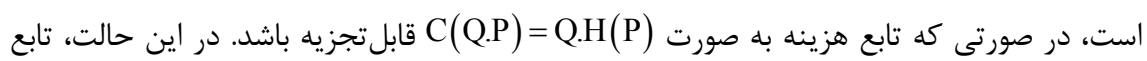
بايد همگن از درجه يك باشد و افزايش مقدار معين نهادها به افزايش همان مقدار در ميزان توليد

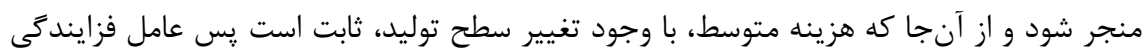

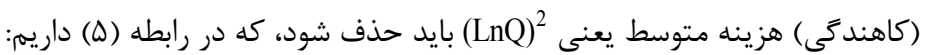
$\mathrm{g}_{\mathrm{iQ}}=\mathrm{g}_{\mathrm{QQ}}=0, \quad \mathrm{i}=\mathrm{K}, \mathrm{L}, \mathrm{E}$ آماره اين فرضيه مانند آماره هموتتيكى با استفاده از نسبت درستنمايى محاسبه مىشود،

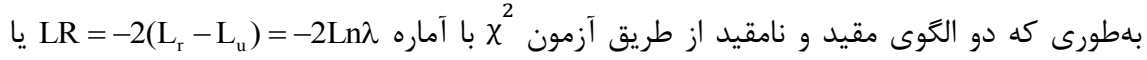

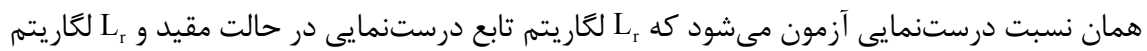
تابع درستنمايى در حالت نامقيد است (Gervais et al., 2006).

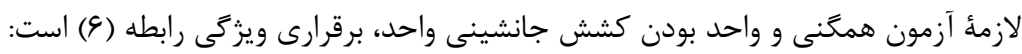
$\gamma_{\mathrm{QQ}}=\gamma_{\mathrm{iQ}}=\gamma_{\mathrm{ii}}=0, \quad \mathrm{i}=\mathrm{K}, \mathrm{L}, \mathrm{E}$

براى اين آزمون، ابتدا بايد تابع هزينه به صورت نامقيد و سيس مقيد برآورد شود. سيس بايد با آنا

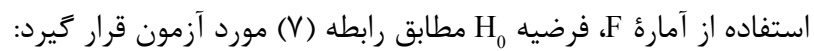
$F_{(R, d, f)}=\frac{S_{R S} / S_{S E}}{S S E_{I J} / d f}$ 


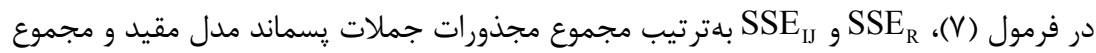

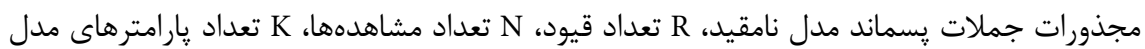

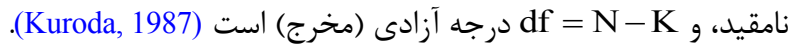
تابع ترانسلوگ از اشكال انعطافيذير و غيرخطى تابع توليد و هزينه است كه براى تخمين مستقيم

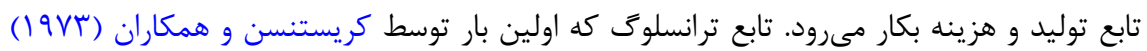
ارائه كرديد، به يروهشكران اجازه مىدهد آزمونهاى مربوط به نظريه توليد و هزينه را رانجام دهند و كششها و ساير يارامترهاى توليد و هزينه را تحت يكسرى حداقل مفروضات اوليه تخمين بزنند كه در اين ارتباط نظريههايى در خصوص ميزان دقت تخمينهاى ترانسلوى از يارامترها وجود دارده

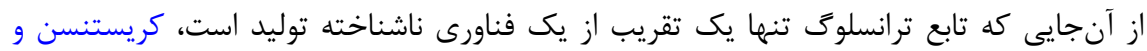

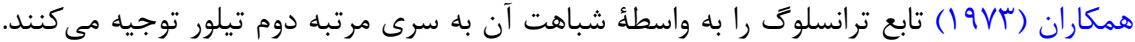

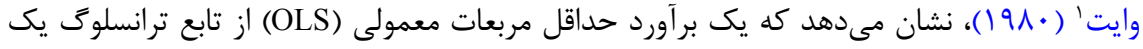

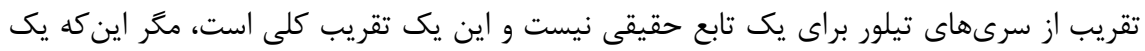

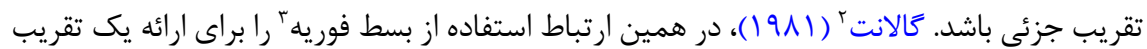
كلى در مورد توابع توليد و مطلوبيت ييشنههاد مى كند. تعدادى از يزوهشكَان نيز از تكنيكهاى

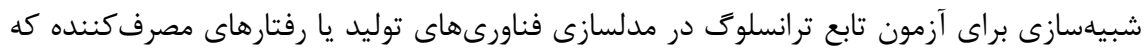
به عنوان كششها شناخته مىشوند، استفاده مى كنند.

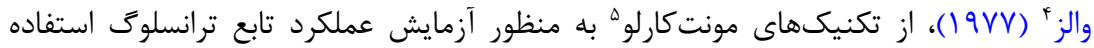
مى كند و تابع مطلوبيت لئونتيف را در يك ترتيب كشش با مقادير متفاوت تعميم مى دهد و درمى يابد

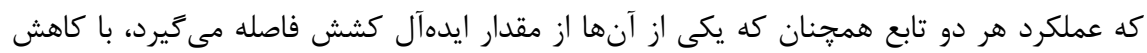
مواجه مىشوند (عدد يك براى تابع ترانسلوى و عدد صفر براى تابع لئونتيف تعميميافته). توليكى دهى إنى و لاول (·191)، آزمايشهاى مونتكارلو را به منظور تشخيص توانايى تابع ترانسلوگ در ايجاد

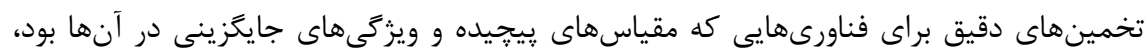

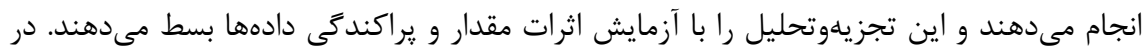
مجموع، آنها نتيجه گيرى مى كنند كه تابع ترانسلوى يك تقريب وابسته از واقعيت ارائه مى دهد،

1. White

2. Gallant

3. Fourier Series 
به شرطى كه اين واقعيت خيلى يِيجيده نباشد. همجنين در ادامه اين يروهش، برنت و كرستيزين'

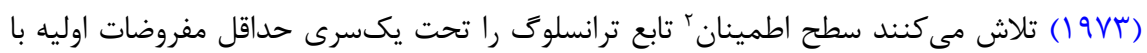

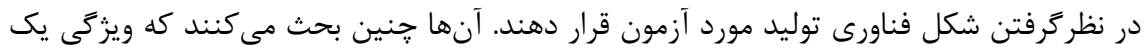

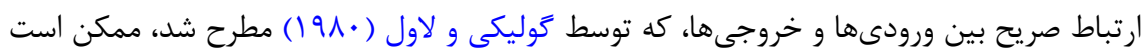
بر تخمينهاى مربوط به كششها اثر بحذارد. آنها در ادامه يك تابع هزينه ترانسلوى را با با رويكرد

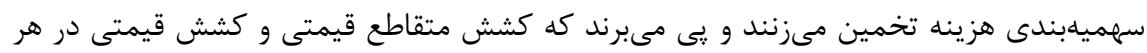

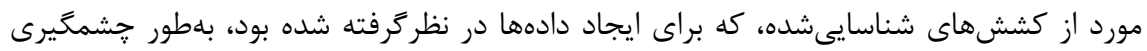
تفاوت دارند (Stern, 1994). يروهشهاى انجامشده نشان مىدهند تابع ترانسلوى يك تخمينزن خوب و معقول براى تابع

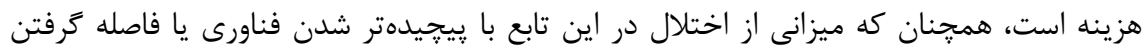

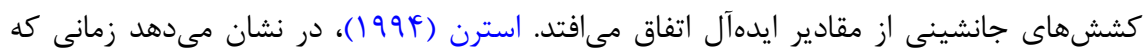

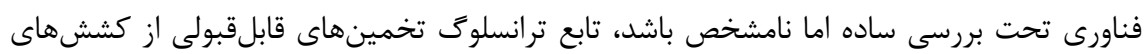

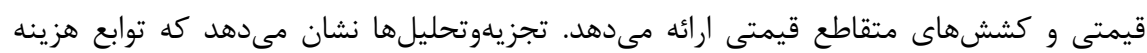

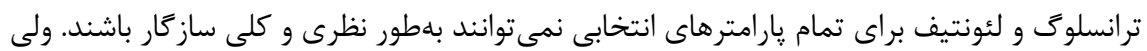

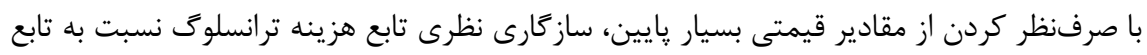
هزينه لئونتيف بسيار بيشتر مىشود.

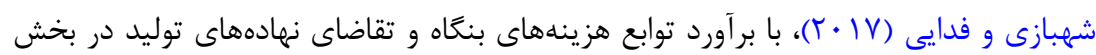
صنعت طى سالهاى

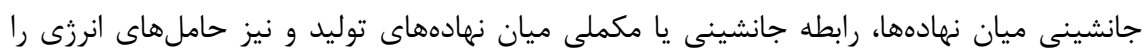

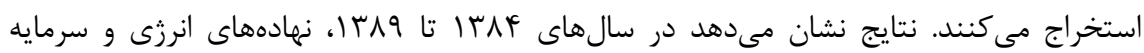
مكمل نيروى كار و نهادهای انرزى و نيروى كار مكمل سرمايه هستند. همجنين سرمايه و نيروى

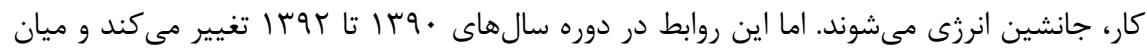

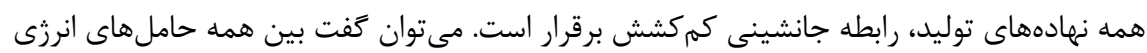

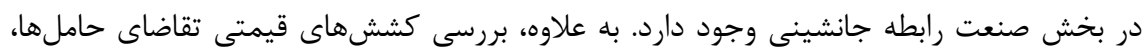

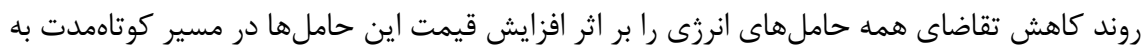

1. Berndt \& Christensen

2. Reliability 


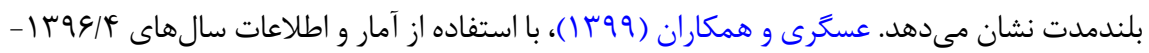

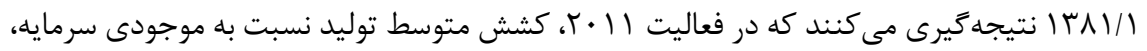

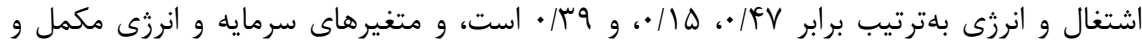
متغيرهاى سرمايه، اشتغال، و انرزى جانشين يكديگر هستند. تحريم بيشترين تاثير منفى را بر

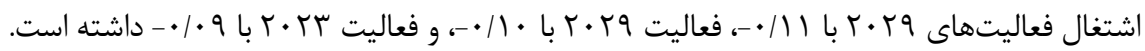

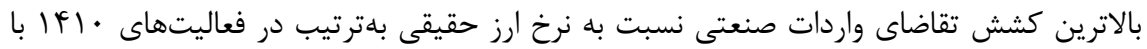

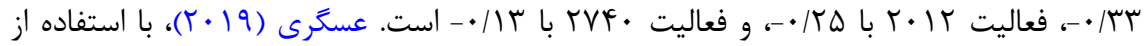

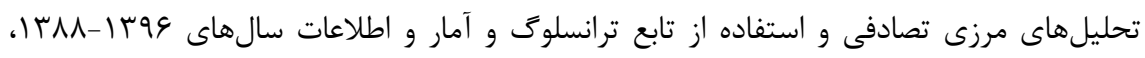
توليد و كارايى فنى بخش صنعت ايران را به تفكيك كدهاى جهار رقمى ISIC محاسبه ميى كند و نتيجه مى گيرد صنايع شيميايى و نفت و زغال سنگ در رتبه اول كارايى، و صنايع نساجى و يوشاى و جرم، صنايع جوب و محصولات جوبى، و صنايع كاغذ و مقوا و جاب و انتشار در رتبه جهارم كارايى

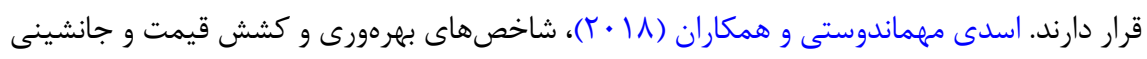
عوامل توليد را به عنوان يارامترهاى مههم بخش صنعت اقتصاد ايران در دو حالت كل عوامل توليد و

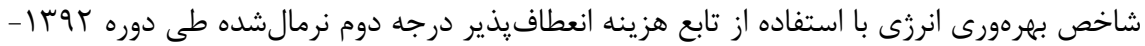
سها إبرآورد مى كنند. نتايج نشان مىدهد متوسط شاخص بهرهورى كل عوامل توليد و شاخص

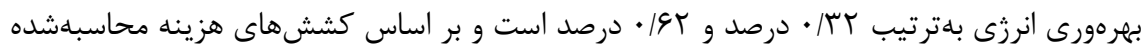

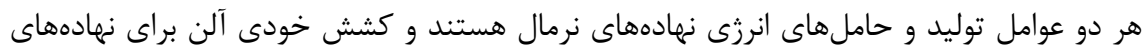
مختلف مطابق نظريه، منفى بوده است. از طرفى، كشش جانشينى موريشيما بين اين دو متغير براى

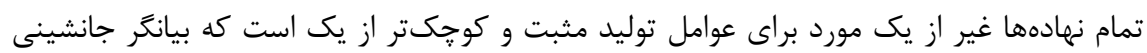

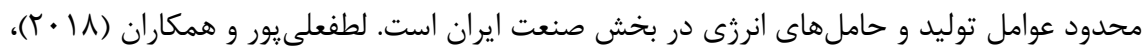
جايگزين كردن نيروى كار بهجاى انرزى و تاثير آن بر اقتصاد را به دليل آثار مخرب مصرف اندئ انرزى بررسى مى كنند. آنها كشش جانشينى بين نهادهاى نيروى كار و انرزى را براى بخش صنش صنعت ايران

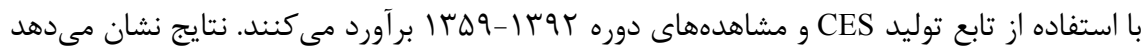

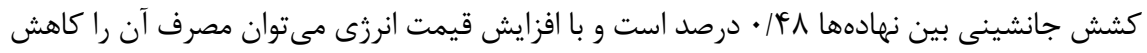
داد و با توجه به جانشينى اين دو نهاده، افزايش تقاضا براى نيروى كار قابلانتظار است. كاغذيان و

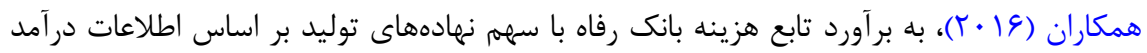

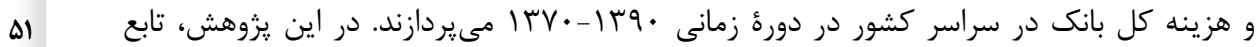


ترانسلوگ براى برآورد پارامترهاى مربوط به معادلات تقاضاى مشتقشده نهادهاى توليد و محاسبه كشش جانشينى قيمت عوامل استفاده شده است. نتايج نشان مى دهد عوامل توليد بانكى رفاه جانشين هم است و كشش متقاطع سرمايه فيزيكى و نيروى انسانى بيشتر از كشش متقاطع نيروى انسانى و سرمايه فيزيكى است كه نشان از تاثير بيشتر سرمايه بر هزينههاى بانك دارد. از طرف ديكر، كشش قيمتى نهاده سرمايه نسبت به ساير نهادهها بيشتر است و بيانكر حساسيت بيشتر ايشر اين نهاده در مقابل تغيير قيمتهاى نهادهاست. همجنين، بانك رفاه با صرفههاى ناشى از مقياس و بازدهى فزاينده

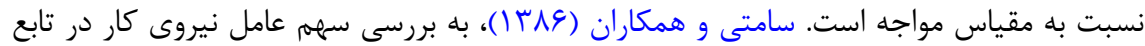

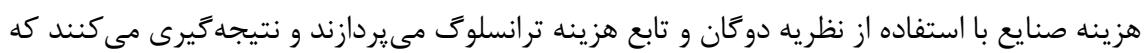

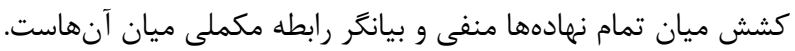

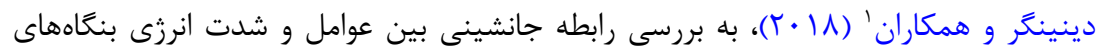

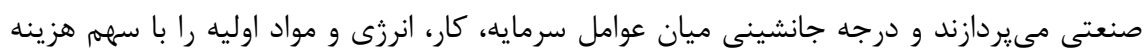

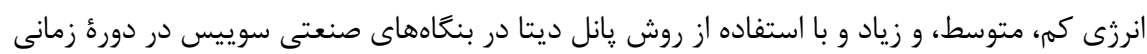

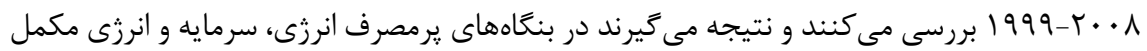

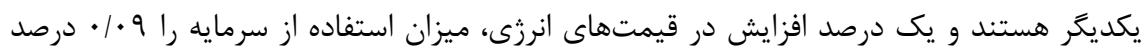

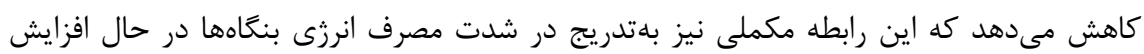

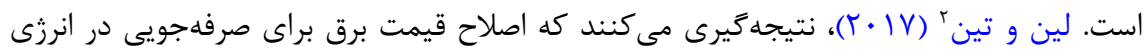

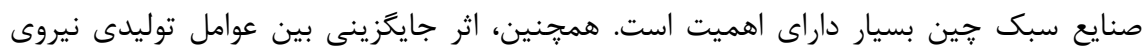

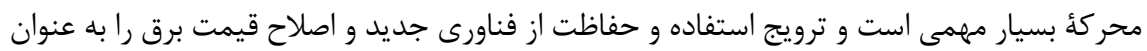

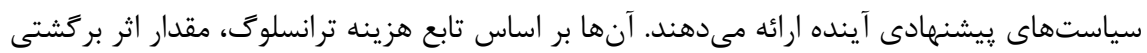

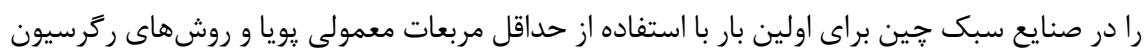
بلظاهر غيرمرتبط تخمين مىزنند و درمىيابند كه با در نظركرفتن اثرات نامتقارن قيمتهاى انرزى

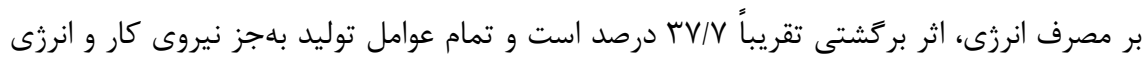

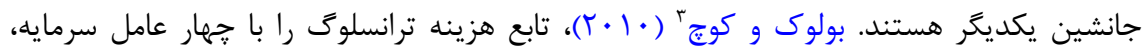

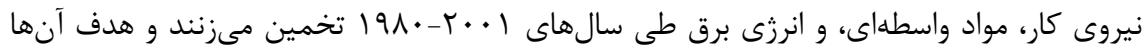
تحليل ساختارى اثرات آزادسازى قيمت برق است. نتايج نشان مى مدهد تقدى نقاضاى برق نسبتاً به قيمت

\section{Deininger et al.}

2. Lin \& Tian

3. Bölük \& Koç 
حساس است و عوامل برق ـ نيروى كار و برق - و سرمايه دوبلدو مكمل هستند، در حالى كه بين

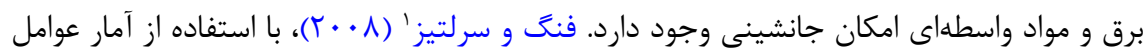
توليد و رويكرد اقتصادسنجى به محاسبه بهرهورى، انحراف تغييرات فناورى، كشش قيمتى، و كشش ونش

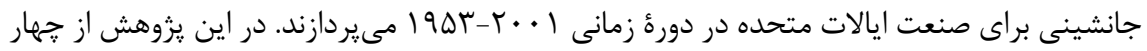

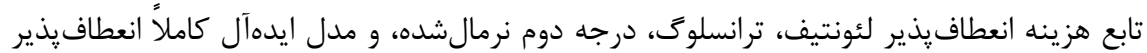
استفاده مىشود.

در اين يزوهش براى ياسخكويى به يرسشهاى مورد نظر از تابع هزينه ترانسلوى استفاده شده

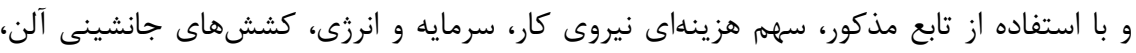
كششهاى قيمتى تقاضا، كششهاى جانشينى موريشيما و نوع ارتباط جانشينى و مكملى عوامل توليد (نيروى كار، سرمايه، و انرزى) بلدست آمده است. رابطه (م)، نشاندهنده توابع توليد و هزينه $\mathrm{Q}=\mathrm{f}(\mathrm{L}, \mathrm{K}, \mathrm{E})$

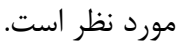

$\mathrm{Q}=\mathrm{AL}^{\alpha} \mathrm{K}^{\beta} \mathrm{E}^{\gamma} \mathrm{e}^{\mathrm{ut}}$

$\mathrm{C}=\mathrm{f}\left(\mathrm{P}_{\mathrm{L}}, \mathrm{P}_{\mathrm{K}}, \mathrm{P}_{\mathrm{E}}, \mathrm{q}\right)$

تابع هزينه ترانسلوى را با استفاده از سه عامل توليد موجودى سرمايه (K)، نيروى كار (L)، انرزى و توليد (q) به صورت رابطه (q) تصريح مىشود كه قيمت سرمايه (PK)، دستمزد (PL)، قيمت (PL) انرزى (P))، هزينه (C) و (C) و إيراتور لكاريتم است.

$\mathrm{C}=\mathrm{f}\left(\mathrm{P}_{\mathrm{L}}, \mathrm{P}_{\mathrm{K}}, \mathrm{P}_{\mathrm{E}}, \mathrm{q}\right)$

$\mathrm{LnC}=\alpha+\beta_{\mathrm{K}} \operatorname{LnP}_{\mathrm{K}}+\beta_{\mathrm{L}} \operatorname{LnP}_{\mathrm{L}}+\beta_{\mathrm{E}} \operatorname{LnP}_{\mathrm{E}}+\beta_{\mathrm{KK}} 1 / 2 \operatorname{Ln}^{2} \mathrm{P}_{\mathrm{K}}+\beta_{\mathrm{KL}} \mathrm{LnP}_{\mathrm{K}} \operatorname{LnP}_{\mathrm{L}}+\beta_{\mathrm{KE}} \operatorname{LnP}_{\mathrm{K}} \operatorname{LnP}_{\mathrm{E}}$ $+\beta_{\mathrm{LL}} 1 / 2 \operatorname{Ln}^{2} \mathrm{P}_{\mathrm{L}}+\beta_{\mathrm{LE}} \operatorname{LnP}_{\mathrm{L}} \operatorname{LnP}_{\mathrm{E}}+\beta_{\mathrm{EE}} 1 / 2 \operatorname{Ln}^{2} \mathrm{P}_{\mathrm{E}}+\beta_{\mathrm{qK}} \operatorname{LnqLnP}_{\mathrm{K}}+\beta_{\mathrm{qL}} \operatorname{LnqLnP}_{\mathrm{L}}+\beta_{\mathrm{qE}} \operatorname{LnqLnP}_{\mathrm{E}}$ $+\beta_{\mathrm{q}} \mathrm{Lnq}+\beta_{\mathrm{qq}} 1 / 2 \operatorname{Ln}^{2} \mathrm{q}+\varepsilon_{\mathrm{C}}$

براى محاسبه كششها در تابع هزينه ترانسلوگ، معادلات سهم عوامل توليد در رابطه ( • () ارائه

$\mathrm{S}_{\mathrm{K}}=\beta_{\mathrm{K}}+\beta_{\mathrm{KK}} \mathrm{LnP}_{\mathrm{K}}+\beta_{\mathrm{KL}} \mathrm{LnP}_{\mathrm{L}}+\beta_{\mathrm{KE}} \mathrm{LnP}_{\mathrm{E}}+\beta_{\mathrm{qK}} \mathrm{Lnq}+\varepsilon_{\mathrm{K}}$

$\mathrm{S}_{\mathrm{L}}=\beta_{\mathrm{L}}+\beta_{\mathrm{KL}} \mathrm{LnP}_{\mathrm{K}}+\beta_{\mathrm{LL}} \mathrm{LnP}_{\mathrm{L}}+\beta_{\mathrm{LE}} \mathrm{LnP}_{\mathrm{E}}+\beta_{\mathrm{qL}} \mathrm{Lnq}+\varepsilon_{\mathrm{L}}$

$\mathrm{S}_{\mathrm{E}}=\beta_{\mathrm{E}}+\beta_{\mathrm{KE}} \mathrm{LnP}_{\mathrm{K}}+\beta_{\mathrm{LE}} \mathrm{LnP}_{\mathrm{L}}+\beta_{\mathrm{EE}} \mathrm{LnP}_{\mathrm{E}}+\beta_{\mathrm{qE}} \mathrm{Lnq}+\varepsilon_{\mathrm{E}}$ 
در سيستم معادلات ( • ()، ها يارامتر وجود دارد كه با استفاده از شروط تقارن ارائهشده در رابطه

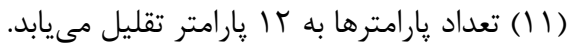

$\beta_{\mathrm{KL}}=\beta_{\mathrm{LK}}, \quad \beta_{\mathrm{KE}}=\beta_{\mathrm{EK}}, \quad \beta_{\mathrm{EL}}=\beta_{\mathrm{LE}}$

كه با توجه به فرض همگن بودن ضرايب نسبت به قيمتها خواهيم داشت:

$\beta_{\mathrm{K}}+\beta_{\mathrm{L}}+\beta_{\mathrm{E}}=1 \quad \rightarrow \quad \beta_{\mathrm{E}}=1-\left(\beta_{\mathrm{K}}+\beta_{\mathrm{L}}\right)$

$\beta_{\mathrm{KK}}+\beta_{\mathrm{LK}}+\beta_{\mathrm{EK}}=0 \rightarrow \beta_{\mathrm{EK}}=-\left(\beta_{\mathrm{KK}}+\beta_{\mathrm{LK}}\right)$

$\beta_{\mathrm{KL}}+\beta_{\mathrm{LL}}+\beta_{\mathrm{EL}}=0 \rightarrow \beta_{\mathrm{EL}}=-\left(\beta_{\mathrm{KL}}+\beta_{\mathrm{LL}}\right)$

$\beta_{\mathrm{KE}}+\beta_{\mathrm{LE}}+\beta_{\mathrm{EE}}=0 \quad \rightarrow \quad \beta_{\mathrm{EE}}=-\left(\beta_{\mathrm{KE}}+\beta_{\mathrm{LE}}\right)$

$\beta_{\mathrm{qE}}=-\left(\beta_{\mathrm{qK}}+\beta_{\mathrm{qL}}\right)$

$\beta_{\mathrm{LE}}=\beta_{\mathrm{KE}}=0$

شرط خطى بودن نيز در رابطه (ب ا) بيان شده است.

$\mathrm{C}=\sum_{\mathrm{i}=1}^{3} \mathrm{P}_{\mathrm{i}} \mathrm{x}_{\mathrm{i}}, \quad \mathrm{S}_{\mathrm{i}}=\frac{\mathrm{P}_{\mathrm{i}} \mathrm{x}_{\mathrm{i}}}{\mathrm{C}}, \quad \sum_{\mathrm{i}=1}^{3} \mathrm{~S}_{\mathrm{i}}=1$

در ادامه، يارامترهاى مربوط به متغير انرزى يا همان E با استفاده از رابطه (Y) در رابطه (9)

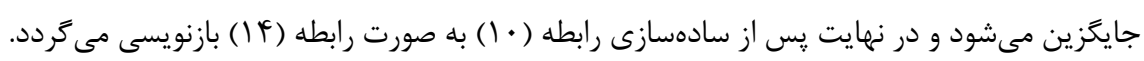
$\mathrm{S}_{\mathrm{K}}=\beta_{\mathrm{K}}+\beta_{\mathrm{KK}} \operatorname{Ln}\left(\frac{\mathrm{P}_{\mathrm{K}}}{\mathrm{P}_{\mathrm{E}}}\right)+\beta_{\mathrm{KL}} \operatorname{Ln}\left(\frac{\mathrm{P}_{\mathrm{L}}}{\mathrm{P}_{\mathrm{E}}}\right)+\beta_{\mathrm{qK}} \operatorname{Lnq}+\varepsilon_{\mathrm{K}}$

$\mathrm{S}_{\mathrm{L}}=\beta_{\mathrm{L}}+\beta_{\mathrm{KL}} \operatorname{Ln}\left(\frac{\mathrm{P}_{\mathrm{K}}}{\mathrm{P}_{\mathrm{E}}}\right)+\beta_{\mathrm{LL}} \operatorname{Ln}\left(\frac{\mathrm{P}_{\mathrm{L}}}{\mathrm{P}_{\mathrm{E}}}\right)+\beta_{\mathrm{qL}} \operatorname{Lnq}+\varepsilon_{\mathrm{L}}$

كششهاى تابع هزينه ترانسلوكى

كشش جانشينى آلن-اوزاوا بيانكر تغييرات درصدى در نسبت دو عامل توليدى ناشى از يك درصد

تغيير در قيمتهاى نسبى آنهاست و براى مشخص نمودن رابطه جانشينى و مكملى بين هر جفت

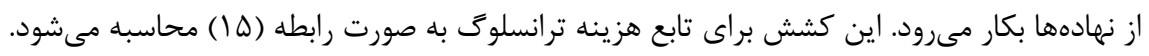




$$
\mathrm{AES}_{\mathrm{ij}}=\frac{\sum \mathrm{f}_{\mathrm{i}}}{\mathrm{X}_{\mathrm{i}}}, \frac{\mathrm{X}_{\mathrm{i}}}{\mathrm{X}_{\mathrm{j}}}, \frac{\left|\mathrm{B}_{\mathrm{ij}}\right|}{|\mathrm{B}|}
$$

$$
\operatorname{AES}_{\mathrm{ij}}=\frac{\left(\gamma_{\mathrm{ij}}+\mathrm{S}_{\mathrm{i}} \mathrm{S}_{\mathrm{j}}\right)}{\mathrm{S}_{\mathrm{i}} \mathrm{S}_{\mathrm{j}}}, \quad \mathrm{AES}_{\mathrm{ii}}=\frac{\left(\gamma_{\mathrm{ii}}+\mathrm{S}_{\mathrm{i}}^{2}-\mathrm{S}_{\mathrm{j}}\right)}{\mathrm{S}_{\mathrm{i}}^{2}}
$$

در رابطه (1))، AES و AES

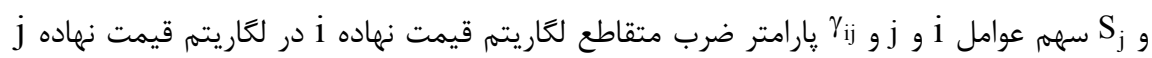
در تابع ترانسلوى است. در ارتباط با كششهاى جزئى خودى آلن، علامت مورد انتظار منفى است،

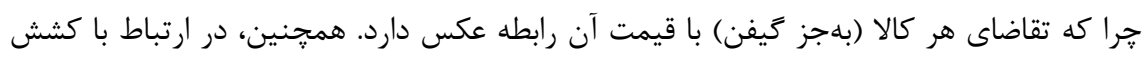

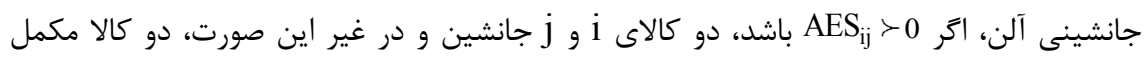

\section{كشث قيمتى عوامل توليد}

كششهاى قيمتى تقاضاى نهادهها به عنوان شاخص حساسيت نسبى تقاضا به نوسانات قيمت و

كشش متقاطع قيمتى تقاضا، با فرض ثبات قيمت ساير نهادههاى توليدى براى تبيين رابطه جانشينى

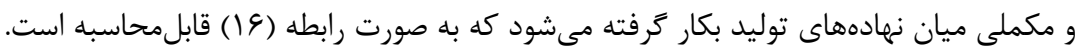
$\varepsilon_{\mathrm{ij}}=\frac{\left(\gamma_{\mathrm{ij}}+\mathrm{S}_{\mathrm{i}} \mathrm{S}_{\mathrm{j}}\right)}{\mathrm{S}_{\mathrm{i}}}, \quad \varepsilon_{\mathrm{ii}}=\frac{\left(\gamma_{\mathrm{ii}}+\mathrm{S}_{\mathrm{i}}^{2} \mathrm{~S}_{\mathrm{j}}\right)}{\mathrm{S}_{\mathrm{i}}}$ $\varepsilon_{\mathrm{ij}} \neq \varepsilon_{\mathrm{ji}} \quad \mathrm{i}, \mathrm{j}=\mathrm{K}, \mathrm{L}, \mathrm{E}$

$\varepsilon_{\mathrm{ii}}=\operatorname{AES}_{\mathrm{ii}} \cdot \mathrm{S}_{\mathrm{i}}$ $\mathrm{i}=\mathrm{j}$

$\varepsilon_{\mathrm{ij}}=\mathrm{AES}_{\mathrm{ij}} \cdot \mathrm{S}_{\mathrm{j}}$

$\varepsilon_{\mathrm{ji}}=\mathrm{AES}_{\mathrm{ij}} \cdot \mathrm{S}_{\mathrm{i}}$ $\mathrm{i} \neq \mathrm{j}$

ع و ع عاترتيب كشش قيمتى خودى تقاضا و كشش قيمتى متقاطع تقاضاى نهادهها را نشان

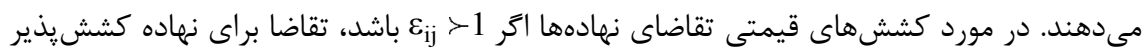

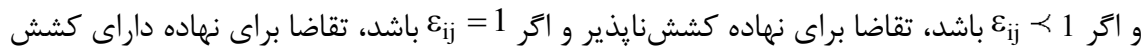

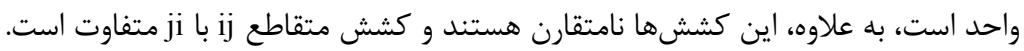

\section{كش موريشيما}

كشش جانشينى موريشيما با استفاده از رابطه (IV) قابل محاسبه است. 
كه

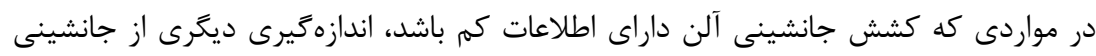

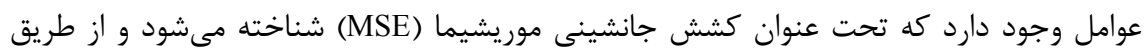

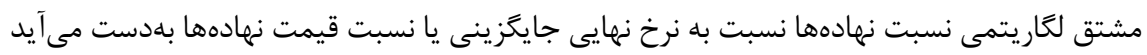
$\mathrm{MES}_{\mathrm{ij}}=\partial \frac{\left(\ln \mathrm{X}_{\mathrm{i}} / \mathrm{X}_{\mathrm{j}}\right)}{\partial \ln \mathrm{P}_{\mathrm{j}}}=\left(\frac{\beta_{\mathrm{ji}}}{\mathrm{S}_{\mathrm{i}}}\right)-\left(\frac{\beta_{\mathrm{ij}}}{\mathrm{S}_{\mathrm{j}}}\right)+1=\mathrm{AES}_{\mathrm{ij}}-\mathrm{AES}_{\mathrm{jj}}$, for $\mathrm{i} \neq \mathrm{j}$

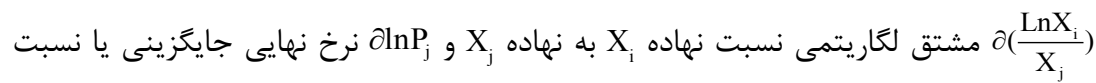

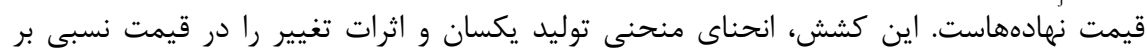

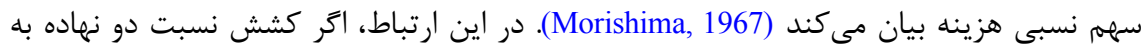
يكديكر مثبت و بزركتر از يك باشد، جانشينى قوى بين آن جفت نهين نهاده وجود دارد كه اين موضوع در

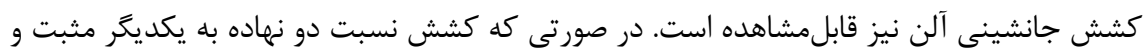

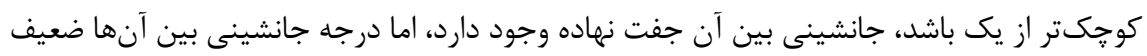

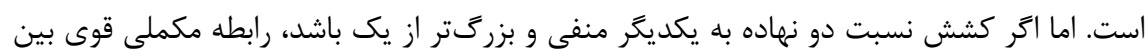

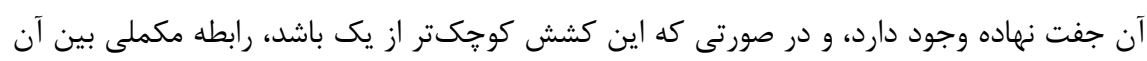
دو نهاده ضعيف است.

كشش خودى و جانشينى آلن-اوزاوا بيانكر تغييرات درصدى در نسبت دو عامل توليدى، ناشى از يك درصد تغيير در قيمتهاى نسبى آنهاست و براى تشخيص قابليت جانشينى و مكملى هر جفت

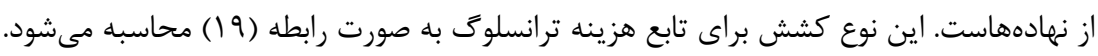
$\mathrm{AES}_{\mathrm{ii}}=\frac{\gamma_{\mathrm{ij}}+\mathrm{S}_{\mathrm{i}}^{2}+\mathrm{S}_{\mathrm{i}}}{\mathrm{S}_{\mathrm{i}}^{2}} \mathrm{i}=\mathrm{j} \quad, \quad \mathrm{AES}_{\mathrm{ij}}=\frac{\gamma_{\mathrm{ij}}}{\mathrm{S}_{\mathrm{i}} \mathrm{S}_{\mathrm{j}}}+1 \mathrm{i} \neq \mathrm{j}$ بES و AES AES $_{i i}$

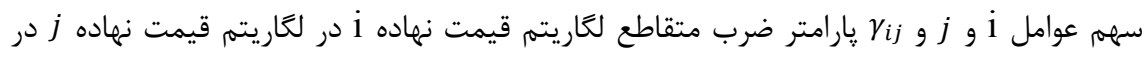
تابع ترانسلوى است. در ارتباط با كششهاى جزئى خودى آلن، انتظار بر اين است كه علايم اين نوع

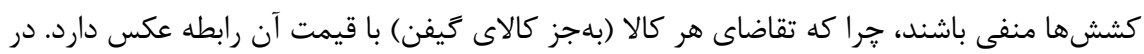

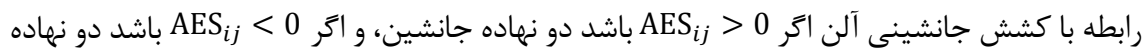




\section{كثش مقياس}

اغلب به صورت افزايش در توليد تعريف مىشود، هنگًامى كه همه نهادهها به يك نسبت افزايش

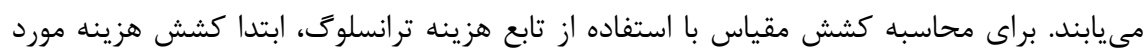
محاسبه قرار مى گيرد، سيس كشش مقياس به صورت معكوس كشش هزينه تعريف مى مى مود كه بهترتيب از طريق رابطه (1) محاسبه مىشود. مئ.

$\varepsilon_{\mathrm{C}}=\frac{\partial \mathrm{LnC}}{\partial \mathrm{Lnq}}=\frac{\mathrm{MC}}{\mathrm{AC}}=\beta_{\mathrm{q}}+\beta_{\mathrm{qq}} \mathrm{Lnq}+\sum_{\mathrm{i}=1}^{3} \beta_{\mathrm{iq}} \mathrm{LnP}_{\mathrm{i}}=\frac{\partial \mathrm{C}}{\partial \mathrm{q}} \cdot \frac{\mathrm{q}}{\mathrm{C}}$

$\varepsilon_{\mathrm{S}}=\frac{1}{\varepsilon_{\mathrm{C}}}=\left(\varepsilon_{\mathrm{C}}\right)^{-1}$

اخر كشش مقياس 1

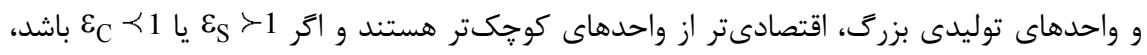

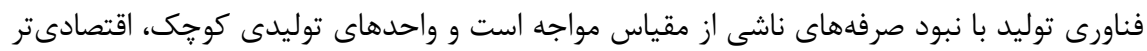
از واحدهاى بزرى هستند.

بهمنظور برآورد تابع هزينه از يك دستعاه معادلات همزمان، بلهور عام از روش رگرسيون

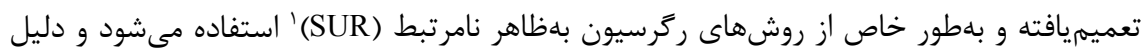
استفاده از اين روش، وجود همبستخى بين جملات اخلال است. دليل وجود ارتباط بين جملات اخلال

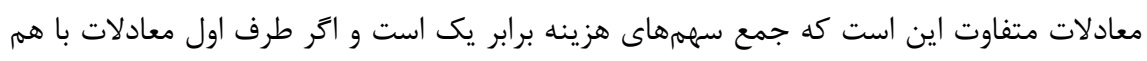

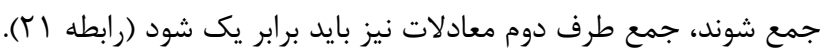

$\sum_{i=1}^{n} \beta_{i}=1$

$\sum_{\mathrm{i}=1}^{\mathrm{n}} \gamma_{\mathrm{ij}}=0$

$\sum_{\mathrm{i}=1}^{\mathrm{n}} \gamma_{\mathrm{ji}}=0$

جمع جملات اخلال معادلات بايد برابر صفر باشد و اين به مفهوم ارتباط خطى جملات اخلال معادلات متفاوت است و جون متغيرهاى مستقل تمام معادلات تقاضا يكسان است، مجموعه تمام

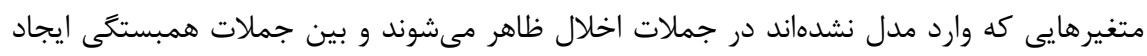
مى كنند (Moss et al., 2003).

در روش SUR فرض مىشود بين جملات اخلال يك معادله خودهمبستخى وجود ندارد و اين 
جملات داراى واريانس همسان هستند. در حالى كه جملات اخلال در معادلات متفاوت داراى واريانس ناهمسانى هستند. از طرف ديخر، همبستكى همزمانى بين جملات اخلال معادلات متفاوت وجود دارد، ولى همبستكى غيرهمزمانى بين جملات اخلال معادلات متفاوت وجود ندارد. زيرا در روش SUR در مرحله اول، مجموعه معادلات به صورت تكمعادله به روش حداقل مربعات معمولى (OLS)' برآورد

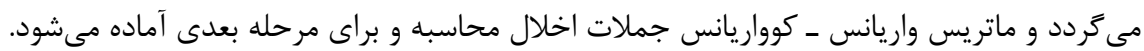

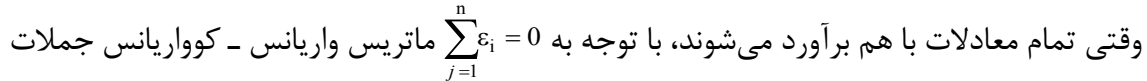
منفرد خواهند بود و امكان تخمين وجود نخواهد داشت (كجراتى، ه^ץ | ). اين كه كدام يك از معادلات بايد از سيستم معادلات حذف شود، اغلب در روش SUR معادلهاى حذف مىشود كه كمترين سهرم

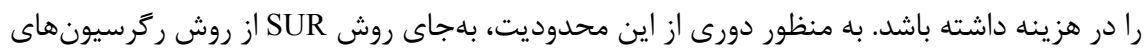

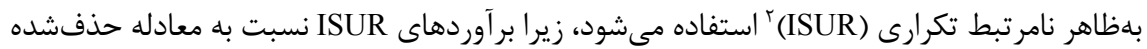

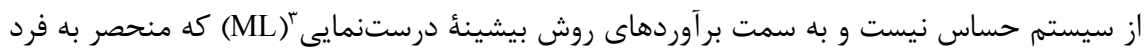

و مستقل از معادله حذفشده است، همكرا مىشوند (Alvarez \& Lawrence, 2008).

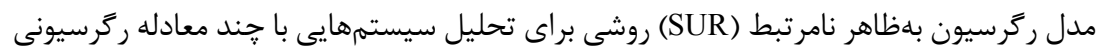
مرتبط است. اين مدل براى تحليل هر معادله ركرسيونى، با بكارگيرى همزمان اطلاعات موجود در مشاهدههاى آن معادله و اطلاعات موجود در مشاهدههاى ساير معادلات، كارايى برآورد يارامترها را افزايش مى دهد. مدل ركرسيون بهظاهر نامرتبط در بسيارى از علوم، بلويزه در اقتصاد، كاربرد دارد. از آنجا كه سيستم معادلات همزمان به لحاظ ساختارى متفاوت با ركرسيونهاى جندمتئغيره

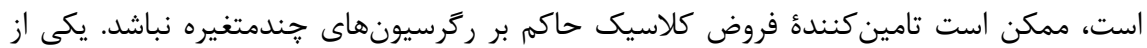
مشخصههاى سيستم معادلات همزمان اين است كه متغير وابسته در يك معادله به عنوان متغيرى توضيحى در معادلهاى ديكر از سيستهم ظاهر مىشود. جنين متغير توضيحى ممكن است با جمله

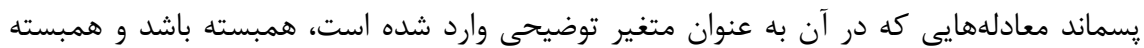

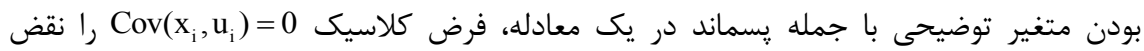

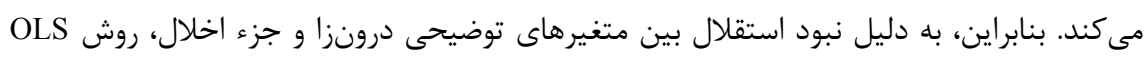

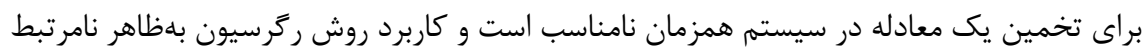
كارايى بيشترى در اين موارد دارد. يك سيستم بلظاهر نامرتبط تركيبى از جندين رابطه مجزا

1. Ordinary Least Squares (OLS)

2. Iterative Seemingly Unrelated Regression (ISUR)

3. Maximum Likelihood (ML) 
(منفرد) است كه بر اساس همبستكى اجزاى اخلال خود با هم رابطه دارند. دو مزيت روش SUR آن است كه اين روش بر اساس تركيب اطلاعات معادلات متفاوت تخمين كارايى را بلهدت مى ميدهد و و ديخرى، قيودى را كه شامل پارامترهاى معادلات مختلف است نيز لحاظ مى كند، كه مىتوان كفت بر

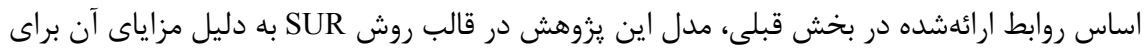
تخمين مدل انتخاب شده است. براى اين كه مدل را با استفاده از روش SUR برآورد كنيم، بايد بين اجزاى اخلال مدل براى دو

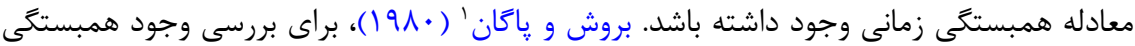

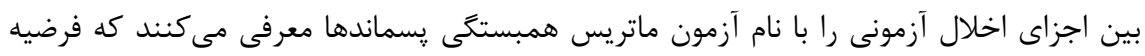

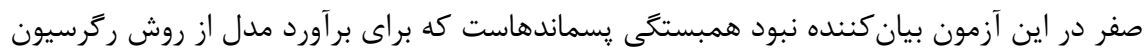

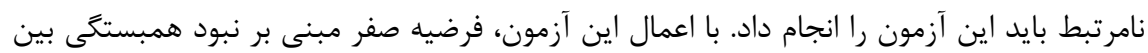

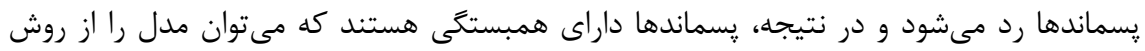

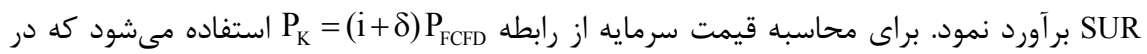

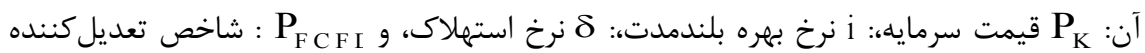

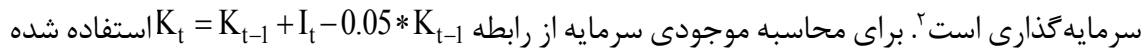

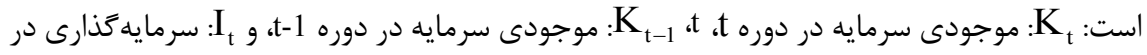

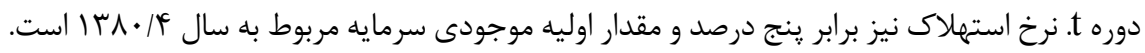

\section{دادهoا}

دادههاى مورد استفاده در اين يزوهش از مركز آمار ايرانّ دريافت شده است و شامل دورهٔ زمانى

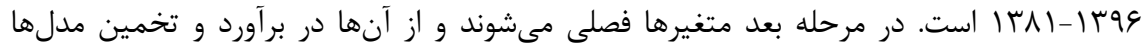

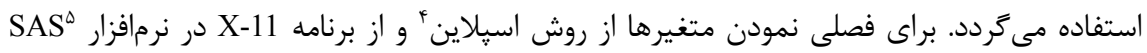

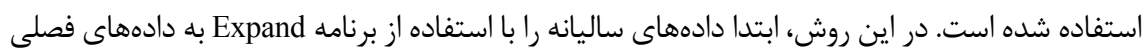
تبديل مى كنيه. در مرحله بعد، يك منحنى اسيلاين درجه سوم را به مقادير اوليه دادهها (تبديلشده به به رهاي برازش مى كنيم كه البته بايد بهترين برازش (مجموع مربع خطاهاى حداقل) باشد. در اينجا

1. Breusch \& Pagan

2. Gross Fixed Capital Formation Deflator (FCFD)

3. https://www.amar.org.ir

5. Statistical Analysis System 
تابع اسيلاين درجه سوم را به شرطى كه كل منحنى و مشتقهاى اول و دوم آن پييوسته باشند بهدست مى دهد. در مرحله بعد، تحت شرايط فوق بين نقاط اتصال (دادهاى seasonal) يك منحنى بر برازش مى كنيم كه نقاط بهدستآمده از اين منحنى همان دادههاى فصلى تعديلشده (با حذف اثر seasonal) خواهند بود. نياز به يادآورى است كه معيار بهينه بودن برازش منحنى در اين بخش آماره F است و

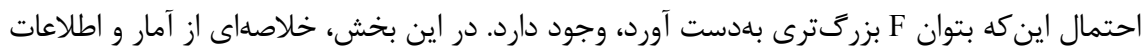
مورد استفاده در مقايسه با كل بخش صنعت كشور در جدول (1) ارائه شده است.

جدول ا: سهم متغيرهاى عمده توليد صنايع شيميايى از بخش صنعت ايران (درصد)

\begin{tabular}{|c|c|c|c|c|c|c|c|c|c|}
\hline انرزى & سرمايه كذارى & صادرات & ارزش افزوده & نهاده & ستانده & دستمزد & اشتغال & تعداد & سال \\
\hline N/AT & N/VG & rr/lq & II/rV & $V / F$. & $q / \bullet$ & $q / 4 q$ & $\Delta / \cdot \Delta$ & $F / F$ & IT人I \\
\hline$N / \cdot r$ & IG/AF & rT/VG & $V / 9 V$ & $V / \cdot V$ & N/r & $9 / 19$ & $\Delta / \cdots$ & $4 / \wedge q$ & ITNT \\
\hline$V / 9$. & $N / \cdot V$ & $r q / T r$ & $1 \cdot 11$ & $V / \Delta \Lambda$ & $\Lambda / \Delta \Lambda$ & D/A & $4 / 19$ & $\Delta / \cdot 1$ & سגו \\
\hline$N / F$ & GIDT & rq/बr & $1 \cdot / K^{F}$ & V/VI & $\Lambda / V$ & $\Delta / 99$ & $\Delta / \cdot V$ & D/I & ITNF \\
\hline Q/VG & rr/Vt & $r \cdot 1 \cdot q$ & $1 \cdot / r \wedge$ & $1 \cdot / r \Delta$ & $1 \cdot / V^{f}$ & g/T & $\Delta / Y)$ & $p / 9 q$ & IrND \\
\hline $1 T / 09$ & אוr/r & FN/GT & $11 / 91$ & $\mid r / \cdots$ & $1 T / 19$ & $9 / 90$ & D/fr & $\omega / r_{q}$ & ITAS \\
\hline $\mid \omega / \Delta G$ & $r V / \Lambda \mid$ & $\Delta N / 11$ & Ir/GT & $1919 \Lambda$ & ID/AT & $V / V \Delta$ & $91 \cdot 9$ & $\Delta / r \Delta$ & IrAV \\
\hline $11 / 90$ & TI/GV & fels. & $|F /|$ & $|r / 1|$ & $|Y / V|$ & $\Lambda / \Delta \Delta$ & G/9 & D/AT & IT人 \\
\hline $19 / 0 \Delta$ & $\mid F / 11$ & $r q / T V$ & $10 / 9 \Delta$ & سואו & $\mid F / T \Delta$ & $9 / \Delta$. & $V / \cdot 9$ & $\Delta / \uparrow q$ & Ir人9 \\
\hline $19 / 09$ & IT/AT & 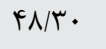 & 19/Fr & $I T / V \Delta$ & $10 / T G$ & $1 \cdot 114$ & V/rr & $\Delta /{ }^{\prime} \wedge$ & וqq. \\
\hline rI/Ar & $r \cdot \mid \wedge \xi$ & $\Delta Y / V F$ & TI/VT & $\mid f / \cdot 1$ & $19 / 19$ & $q / q_{q}$ & $V / T)$ & $\Delta / V \mathcal{F}$ & $|1 q|$ \\
\hline IN/V^ & $\Lambda / 9 \Delta$ & FY/FY & rואז & r & & $q / 1 f$ & $V / 9 \wedge$ & M/r & \\
\hline$r V / l$. & $10 / 4 q$ & $4 q / 94$ & Tr/Fl & $\mid f / 1 \varepsilon$ & $19 / \Delta F$ & q/V. & $V / V I$ & s/rV & سו \\
\hline TE/VT & $\mid r / \cdot \Delta$ & $\Delta / / \Delta$. & $r \cdot / V G$ & $\mid F / r \Lambda$ & $19 / T V$ & سז/• & V/TY & $\Delta / T_{q}$ & irqp \\
\hline$r \cdot 19 V$ & Tr/TD & $f \&|\Delta|$ & $\mid \Lambda / F \wedge$ & $|f / 9|$ & $19 / 11$ & $11 / f F$ & V/rq & $\Delta / 4 \varphi$ & هq \\
\hline rl/s. & If/rT & $F \Delta / / F$ & $r \cdot / r q$ & IF/r & $19 / 19$ & $11 / 94$ & $V / \cdot r$ & $\omega / 1 \omega$ & Irqs \\
\hline$I V / F D$ & $19 / \mathrm{VA}$ & fr/gq & $10 / 99$ & $|r| \cdot F$ & $\mid r / T \wedge$ & $N||^{\mathbb{L}}$ & $\varepsilon / r \wedge$ & $\Delta / r q$ & متوسط دوره \\
\hline
\end{tabular}


براى بررسى جايخاه صنايع شيميايى در بخش صنعت ايران، بهاختصار سهمم متغيرهاى عمده اين صنايع

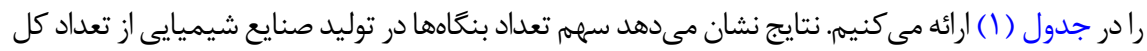

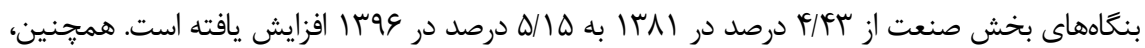

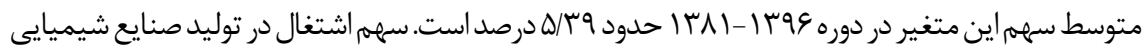

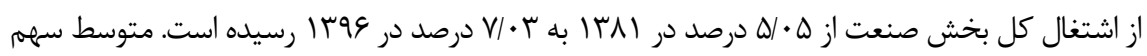

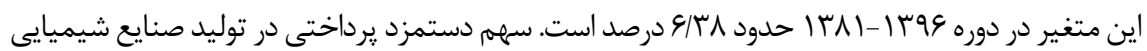

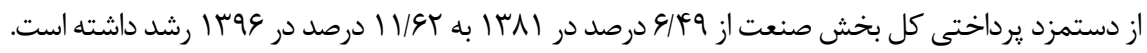

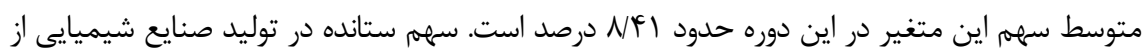

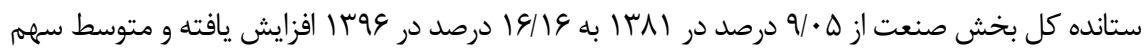

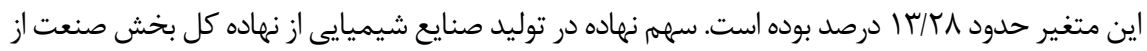

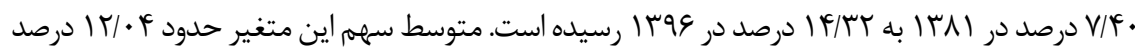

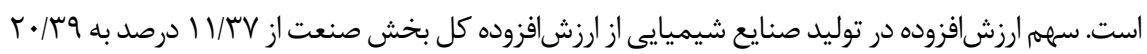

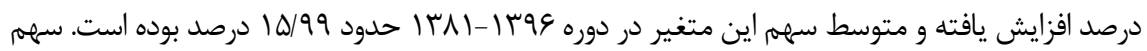

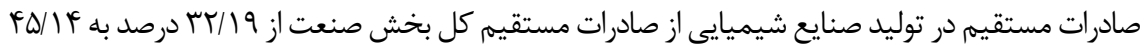

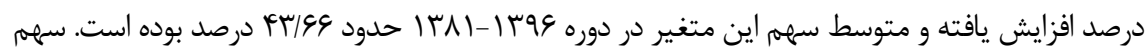

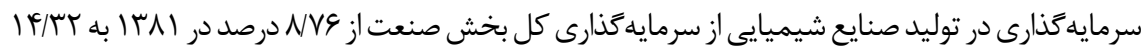

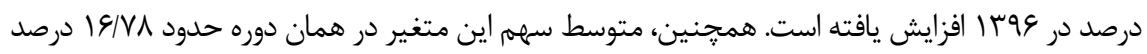
است. در نهايت، سهم انرزى مصرفى در توليد صنايع شيميايى از انرزى مصرفى كل بخش صنعت از N N د درصد

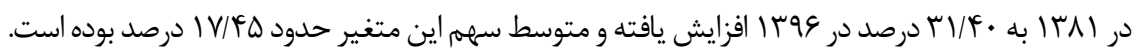

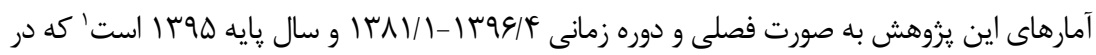
ادامه نتايج تخمين تابع هزينه ترانسلوگ صنايع شيميايى بر اساس كدهاى جهار رقمى (ISIC) داراى • إنفر كاركن و بيشتر صنايع شيميايى در هفت فعاليت توليد مواد شيميايى اساسى (1) (1)، توليد كود شيميايى

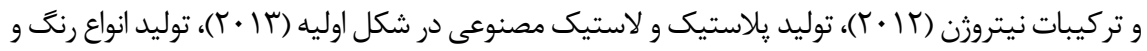
روغن جلاو يوششهاى مشابه (r · ·r)، توليد صابون و شويندهها، تركيبات تميزكننده و براق كننده، عطرهاو

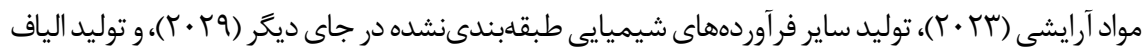

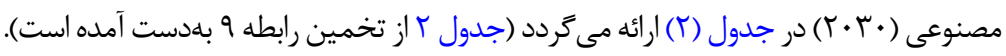


جدول r: بر آورد تابع هزينه صنايع شيميايى

\begin{tabular}{|c|c|c|c|c|c|c|c|}
\hline \multicolumn{3}{|c|}{ هزينه جانشينى } & \multicolumn{3}{|c|}{ هزينه متوسط } & \multirow{2}{*}{ :3: } & \multirow{2}{*}{.3} \\
\hline 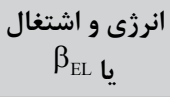 & 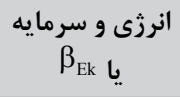 & اشتغال يا مايه و & 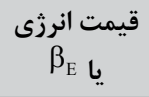 & 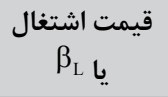 & 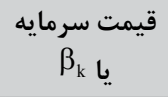 & & \\
\hline$-1 / \cdot \Delta$ & -.194 & -.1 .9 & $\cdot / \mu F$ & $\cdot / r V$ & $\cdot / r q$ & $r \cdot 11$ & \\
\hline$-r / I I$ & $-r / r q$ & $-r|q|$ & $r / r I$ & سT/ & $r / T \Delta$ & t t t t t & 1 \\
\hline$-1 / 4 q$ & $-1 / 79$ & $-\cdot / 1$ & $\cdot / V T$ & . & .110 & $r \cdot I r$ & \\
\hline$-Y|q|$ & $-\Phi / 11$ & س & $r / V I$ & T/TA & $r / 1 \Lambda$ & t t t t t & \\
\hline$-1 / \cdot 9$ & $-\cdot \mid \Lambda s$ & $-\cdot / r \wedge$ &.$/ 49$ & $\cdot / T V$ & $\cdot / T F$ & $r \cdot 1 r$ & $r$ \\
\hline$-Y / V V$ & $-r / F \mid$ & $-r / \cdot F$ & ( & $1 / 99$ & $r / r)$ & t t t t t & \\
\hline$\cdot / 7 q$ & $-\cdot \mid 1 \Lambda$ & . Mt & س & $\cdot / r q$ & $\cdot / \mu \Lambda$ & $r \cdot r r$ & \\
\hline T/Tr & $-Y / V q$ & $r / 9 V$ & r/qV & $r / \cdot 1$ & $r / \cdot \Lambda$ & t t t t & \\
\hline$\cdot / V G$ & $-\cdot / 19$ &.$|9|$ & . & $\cdot / \pi \Delta$ & $\cdot|4|$ & $T \cdot r \mu$ & \\
\hline$r / \Delta \Delta$ & $-r / 91$ & $r / r q$ & T/TT & $r / \cdot 9$ & $1 / 91$ & t & $\omega$ \\
\hline$-1 / .9$ & $-1 / V F$ & $-1 / \cdot 9$ & $.19 \mathrm{~V}$ & .110 & $\cdot 111$ & $r \cdot r q$ & \\
\hline$-r / \cdot 9$ & $-1 / 99$ & $-\boldsymbol{k} / \cdot \boldsymbol{F}$ & F/AV & س & T/TF & t آماره t & \\
\hline$-1 / 19$ & $-1 / 4 T$ & $\cdot 114$ & $\cdot / F F$ & .119 & $\cdot / \mu$ & $r \cdot r \cdot$ & $y$ \\
\hline$-r / r \Lambda$ & $-r / \cdot \Delta$ & $r / 9$. & F/T & T/FT & $r|9|$ & t t t t t & \\
\hline
\end{tabular}

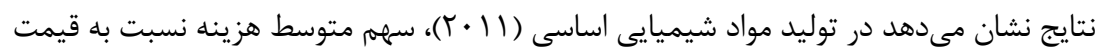

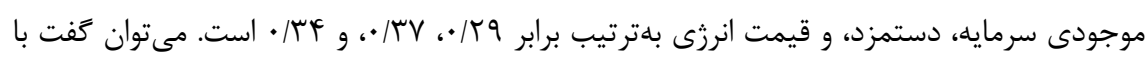
فرض ثبات ساير شرايط، با افزايش يك درصد در قيمت موجودى سرمايه، قيمت نيروى دئ كار، و و قيمت

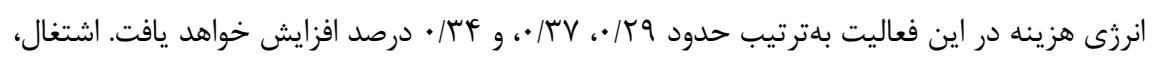

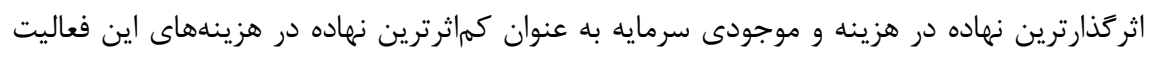

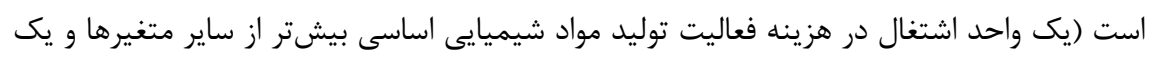

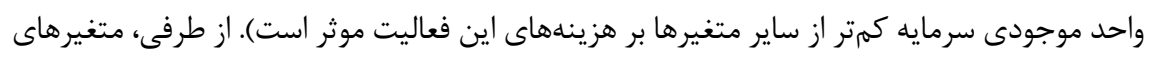

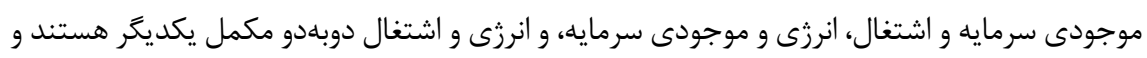
براى صرفهجويى در هزينهها بايد از هر دو نهاده كمتر استفاده شود.

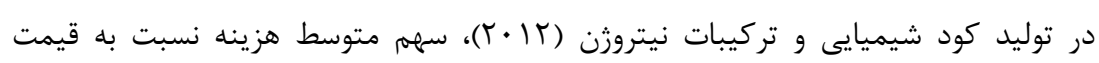




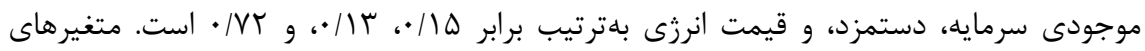

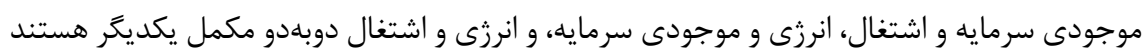
و براى صرفهجويى در هزينهها بايد از هر دو نهاده كمتر استفاده شود. در توليد يلاستيك و لاستيك مصنوعى در شكل نخستين (Y ( • ))، سهم متوسط هزينه نسبت به

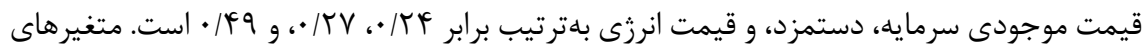
موجودى سرمايه و اشتغال، انرزى و موجودى سرمايه، و انرزى و اشتغال مكمل يكديخر هستند و براى صرفهجويى در هزينهها بايد از هر دو نهاده كمتر استفاده شود.

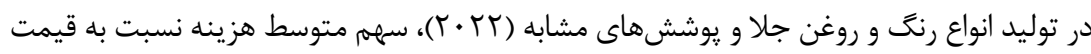

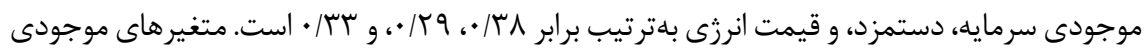

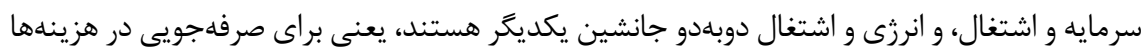

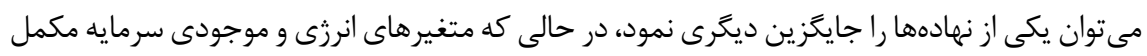
يكديخر هستند و براى صرفهجويى در هزينهها بايد از هر دو نهاده كمتر استر استفاده شود.

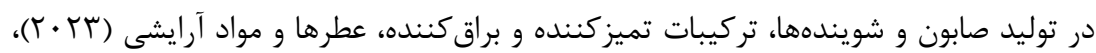

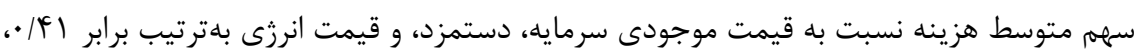

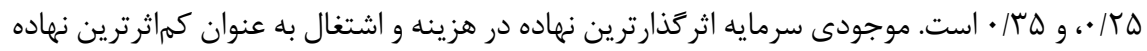
در هزينههاى اين فعاليت است. متغيرهاى موجودى سرمايه و اشتغال، و انرزى و اشتغال جانشين يكديكر هستند، يعنى براى صرفهجويى در هزينهها مى توان يكى از نهادهها را جايكزين ديخرى نمود،

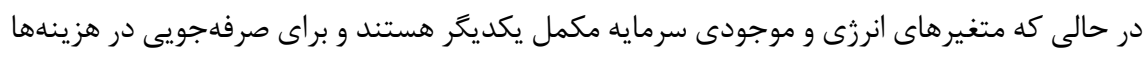
بايد از هر دو نهاده كمتر استفاده شود.

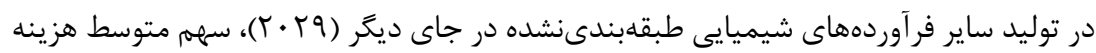

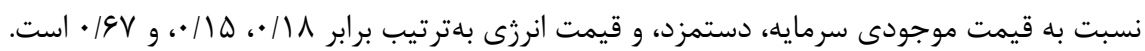

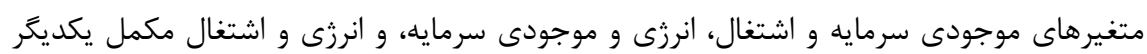

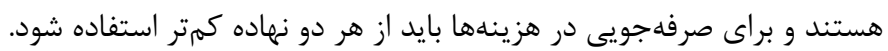

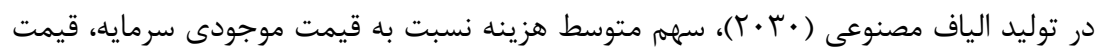

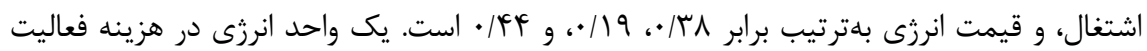
توليد الياف مصنوعى بيشتر از ساير متغيرها و يك واحد اشتغال، كمتر از ساير متغيرها بر هزينههاى اين فين

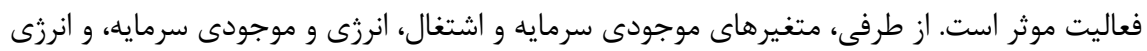


و اشتغال مكمل يكديكر هستند و براى صرفهجويى در هزينهها بايد از هر دو نهاده كمتر استفاده شود.

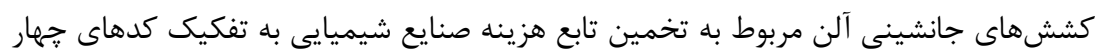

$$
\text { رقمى (ISIC) در جدول (r) ارائه شده است. }
$$

جدول r: كششهاى جانشينى جزئى متقاطع و خودى آلن

\begin{tabular}{|c|c|c|c|c|}
\hline انرزى & سرمايه & كار & كشش & فعاليت \\
\hline$\cdot / \cdot$ & $-\cdot / 11$ &.$- / 1 T$ & كار & \multirow{3}{*}{$r \cdot 11$} \\
\hline$-1 / f \Delta$ & $-\cdot / V V$ & & سرمايه & \\
\hline$-\cdot / V 9$ & & & انرزى & \\
\hline$-\cdot / F F$ & $1 / \cdot$ & $-\cdot \mid \Lambda \varepsilon$ & كار & \multirow{3}{*}{$r \cdot I r$} \\
\hline$-\cdot / I V$ & .119 & & سرمايه & \\
\hline$-\cdot / \mu$ & & & انرزى & \\
\hline$\cdot 1 \cdot 1$ & $-\cdot|4|$ & $-\cdot / \mathrm{A}$ & كار & \multirow{3}{*}{$r \cdot I r$} \\
\hline$-I / A V$ & $-\cdot / F T$ & & سرمايه & \\
\hline$-\cdot / 4$. & & & انرزى & \\
\hline$\cdot / r V$ & $-I / T V$ & $-\cdot / V \wedge$ & كار & \multirow{3}{*}{$T \cdot T r$} \\
\hline$-1 / T F$ & $-\cdot / r V$ & & سرمايه & \\
\hline$-\cdot / r$. & & & انرزى & \\
\hline$\cdot / V r$ & $-r / v q$ & $-1 / 4 \Delta$ & كار & \multirow{3}{*}{$r \cdot r r$} \\
\hline r & $\cdot / 4 \Delta$ & & سرمايه & \\
\hline$-1 / 10$ & & & انرزى & \\
\hline$-\cdot / \mu \Lambda$ & $1 / 49$ & $-\cdot|f|$ & كار & \multirow{3}{*}{$r \cdot r q$} \\
\hline$-r / \cdot \mathcal{F}$ & $-\cdot / 94$ & & سرمايه & \\
\hline$-\cdot / \Gamma \Lambda$ & & & انرزى & \\
\hline$-\cdot / r q$ & $1 / V \Lambda$ & $-\cdot / 4 q$ & كار & \multirow{3}{*}{$r \cdot r}$. \\
\hline سT & -.199 & & سرمايه & \\
\hline$-\cdot / \mathrm{V} \wedge$ & & & انرزى & \\
\hline
\end{tabular}

علامت مورد انتظار براى كششهاى جانشينى جزئى خودى آلن منفى است كه بيانگر رابطه

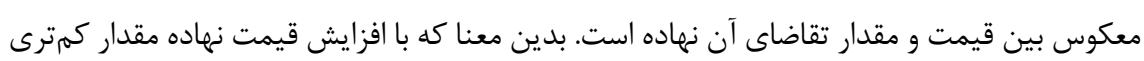


از آن نهاده تقاضا مىشود. قدر مطلق كشش جانشينى جزئى خودى برخى نهادهها كمتر از يك است

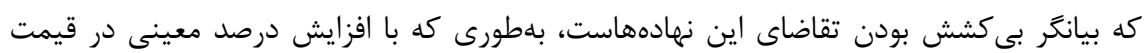

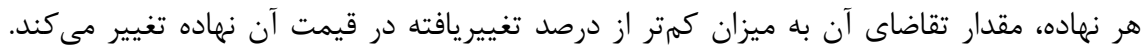
همجنين، مقادير عددى مثبت كششهاى جانشينى جزئى متقاطع آلن نشان مى مدهد كه آن نهادهها

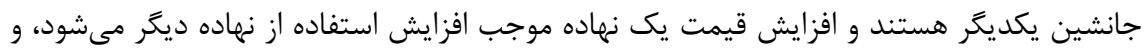

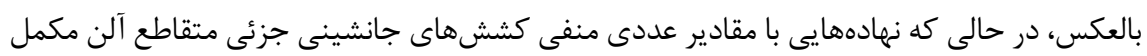

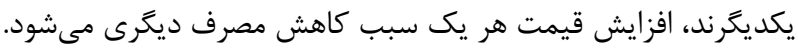

كششهاى قيمتى خودى و متقاطع تقاضاى نهاده مربوط به تخمين تابع هزينه صنايع شيميايى به هـ ميه

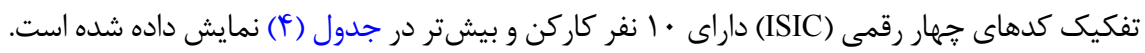

جدول †: كششهاى قيمتى خودى و متقاطع تقاضاى نهادهها

\begin{tabular}{|c|c|c|c|c|}
\hline انرزى & سرمايه & كار & كشش & فعاليت \\
\hline.$/$ & $-\cdot / \cdot k$ & $-\cdot / 4$. & كار & \\
\hline$-\cdot / \& V$ & $\cdot \pi$. & & سرمايه & $r \cdot 11$ \\
\hline$-1 / 10$ & & & انرزى & \\
\hline$-\cdot / \cdot f$ & $\cdot / V V$ & r & كار & \\
\hline.$- / 1 r$ & $-1 / \Gamma \omega$ & & سرمايه & $r \cdot I r$ \\
\hline$-1 / \lambda$ & & & انرزى & \\
\hline$\cdot / \cdot$ & $-\cdot / 1$ & $-\cdot / V q$ & كار & \\
\hline.$- / 49$ & $-1 / k \pi$ & & سرمايه & $r \cdot{ }^{\prime}$ \\
\hline$-\cdot / 94$ & & & انرزى & \\
\hline$\cdot / \cdot \Delta$ & $-\cdot / r q$ & $-\cdot / 4 \lambda$ & كار & \\
\hline$-\cdot / r \wedge$ & $-1 / V \Delta$ & & سرمايه & $r \cdot T r$ \\
\hline.$- / 19$ & & & انرزى & \\
\hline .111 & $-T / F \Delta$ & $-\cdot 19 V$ & كار & \\
\hline$-\cdot / 1 \Delta$ & $-1 / 4 \wedge$ & & سرمايه & $r \cdot r r$ \\
\hline$-I / Y F$ & & & انرزى & \\
\hline
\end{tabular}


ادامه جدول †: كثشهاى قيمتى خودى و متقاطع تقاضاى نهادهها

\begin{tabular}{|c|c|c|c|c|}
\hline انرزى & سرمايه & كار & كشش & فعاليت \\
\hline$-\cdot 1 \cdot V$ & . AT & $-\cdot \mid q \mu$ & كار & \\
\hline$-\cdot / \Lambda \Delta$ & $-1 / \pi$ & & سرمايه & $r \cdot r q$ \\
\hline$\Delta / \cdot r$ & & & انرزى & \\
\hline$-\cdot / \cdot \Delta$ & $\cdot|\Delta|^{F}$ & $-\cdot / T F$ & كار & \\
\hline$-\cdot 191$ & $-1 / 1$ & & سرمايه & $r \cdot r$. \\
\hline$-1 / 1 V$ & & & انرزى & \\
\hline
\end{tabular}

علامت صحيح مورد انتظار براى كششهاى قيمتى خودى تقاضا منفى است كه بيانگر رابطه

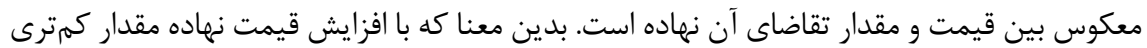

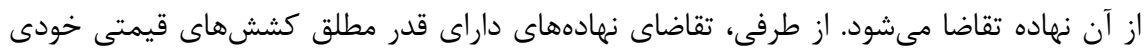
تقاضا و بزرىتر از يك باكشش هستند، بلهطورى كه با افزايش درصد مع معينى در قيمت هر يكى از اين

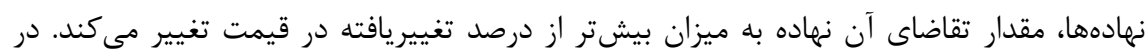
هفت فعاليت مورد بررسى، كشش قيمتى خودى تقاضا براى موجودى سرمايه بهطور كلى بيش از ساير نهادههاست، يعنى حساسيت تقاضاى موجودى سرمايه به تغييرات قيمت خود، بيشتر از بقيه

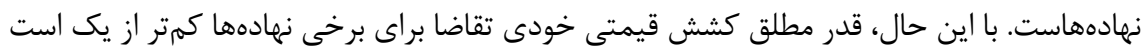
كه بيانكر بى كشش بودن تقاضاى اين نهادههاست، يعنى با افزايش درصد معينى در قيمت هر نهاده،

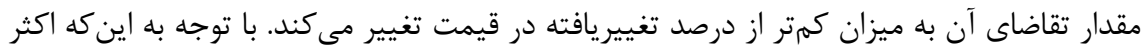
مقادير كششهاى جانشينى متقاطع تقاضا كوٌكى هستند، سياستهاى تغيير قيمت در اين نهادهها

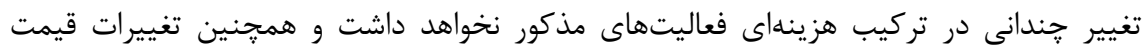
يكى از نهادهها تاثير زيادى بر تقاضاى ديخرى نخواهد داشت. با وجود اين، مقادير نزديك به به يك ياي

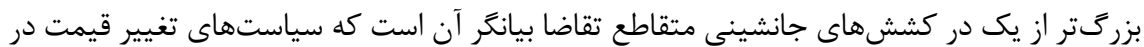
اين نهادهها ممكن است تغييراتى در تركيب هزينهاى فعاليتهاى مذكور ايجاد نمايد و ممكن است تغييرات قيمت يكى از نهادهها تاثير زيادى بر تقاضاى ديكرى داشته باشد. كششهاى متقاطع موريشيما مربوط تخمين تابع هزينه صنايع شيميايى به تفكيك كدهاى جهار رقمى (ISIC) داراى • ا نفر كاركن و بيشتر در جدول (ه) ارائه شده است. 
جدول ه: كششهاى متقاطع موريشيما

\begin{tabular}{|c|c|c|c|}
\hline انرزى & سرمايه & كشش & فعاليت \\
\hline . & $1 / 9$. & \multirow{2}{*}{ سرمايه } & \multirow{2}{*}{$r \cdot 11$} \\
\hline$-\cdot / F r$ & & & \\
\hline$-\cdot / T \cdot$ & $\cdot \mid \Delta V$ & \multirow{2}{*}{ سرمايه } & \multirow{2}{*}{$r \cdot I r$} \\
\hline $1 / r \wedge$ & & & \\
\hline $1 / 11$ & $1 / T r$ & \multirow{2}{*}{ سرمايه } & \multirow{2}{*}{$r \cdot 1 r$} \\
\hline$-1 / 11$ & & & \\
\hline $1 / 19$ & 1/94 & \multirow{2}{*}{ سرمايه } & \multirow{2}{*}{$r \cdot r r$} \\
\hline$-\cdot / T r$ & & & \\
\hline $1 / \cdot \cdot$ & $1 / 99$ & \multirow{2}{*}{ سرمايه } & \multirow{2}{*}{$r \cdot r r$} \\
\hline $1 / 97$ & & & \\
\hline$-1 / \cdot V$ & $-\cdot / V Y$ & \multirow{2}{*}{ سرمايه } & \multirow{2}{*}{$r \cdot r q$} \\
\hline$-1 / 9 \Delta$ & & & \\
\hline$-1 / T V$ & $-1 / 90$ & \multirow{2}{*}{ سرمايه } & \multirow{2}{*}{$r \cdot r \cdot$} \\
\hline$-1 / \cdot r$ & & & \\
\hline
\end{tabular}

در مواردى كه كشش جانشينى آلن داراى اطلاعات كم است، اندازمخيرى ديخرى از جانشينى

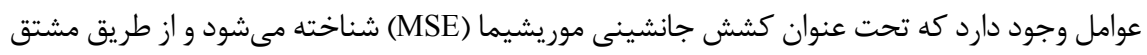

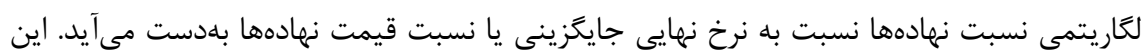
كشش، انحناى منحنى توليد يكسان و اثرات تغيير در قيمت نسبى را بر سهم نسبى هزينه بيان مى كند.

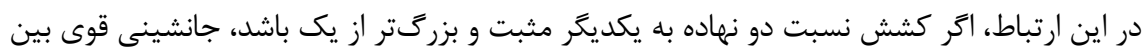

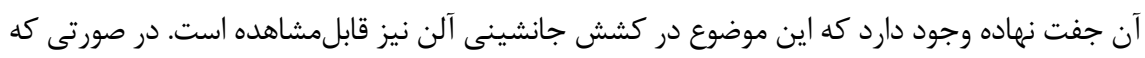

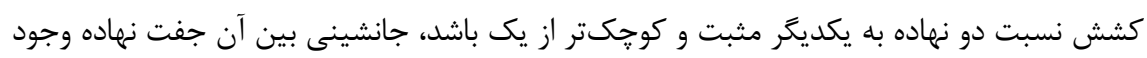

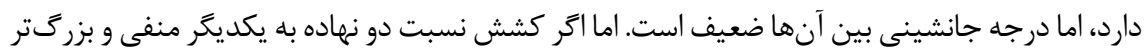

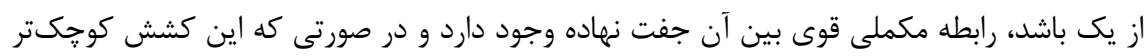

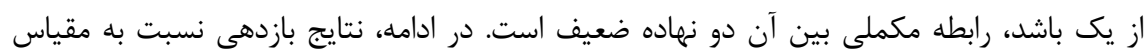

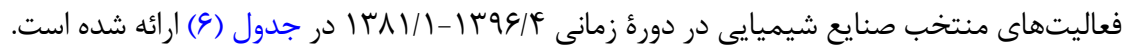




\begin{tabular}{|c|c|c|c|}
\hline كشش مقياس & 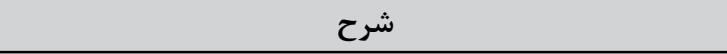 & كد & رديف \\
\hline $1 / \cdot 1$ & توليد مواد شيميايى اساسى & $r \cdot 11$ & 1 \\
\hline $1 / 11$ & توليد كود شيميايى و تركيبات نيتروزن & $r \cdot 1 r$ & r \\
\hline $1 / \cdot r$ & توليد يلاستيك و لاستيك مصنوعى در شكل اوليه & $r \cdot 14$ & r \\
\hline $1 / \cdot 9$ & توليد انواع رنخ و روغن جلاو يوششهاى مشابه & $r \cdot r t$ & r \\
\hline $1 / 1 \cdot$ & توليد صابون و شويندها، تركيبات تميزكننده و براق كننده، عطرها و & $r \cdot r$ & $\Delta$ \\
\hline $1 / \cdot V$ & توليد ساير فرآوردههاى شيميايى طبقهبندىنشده در جاى ديكر & $r \cdot r q$ & द \\
\hline $1 / \cdot r$ & 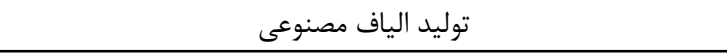 & $r \cdot r \cdot$ & $\checkmark$ \\
\hline
\end{tabular}

ملاحظه مى گردد كه تمام هفت فعاليت مورد بررسى داراى بازدهى فزاينده نسبت به مقياس

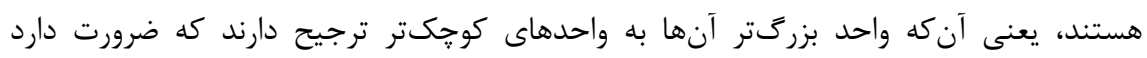
سياستخذار اين بازدهى فزاينده نسبت به مقياس را مورد توجه قرار دهد. توليد كود شيميايى و وند

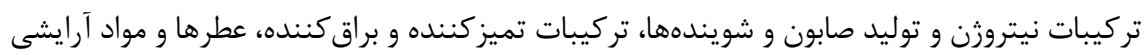
داراى بازدهى بالاترى نسبت به ساير فعاليتها هستند.

در جدول (V)، كششهاى قيمتى انواع انرزى به تفكيك (كل انرزى، كازوييل، كاز طبيعى، بنزين،

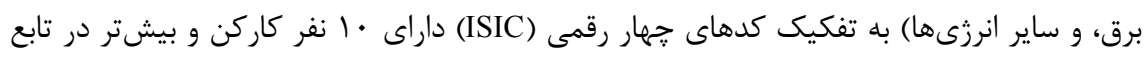

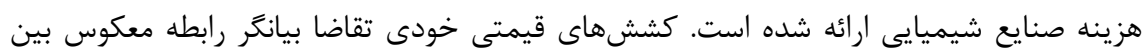

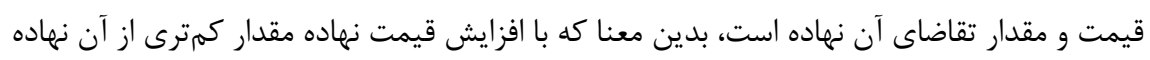

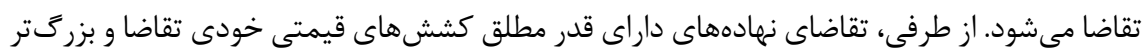
از يك باكشش هستند. 


\section{جدول Y: كثش قيمتى انرخى}

\begin{tabular}{|c|c|c|c|c|c|c|}
\hline ساير انرزىها & برق & بنزين & كاز طبيعى & كازوييل & كل انرزى & فعاليت \\
\hline$-\cdot / \cdot V$ & $-\cdot / f F$ & $-\cdot / \cdot 1$ & $-\cdot|\Delta|$ & $-\cdot / \cdot r$ & $-1 / \cdot V$ & $r \cdot 11$ \\
\hline$-\cdot 1 \cdot \Delta$ & $-\cdot / f F$ & $-\cdot / \cdot 1$ & $-\cdot / V 9$ & $-\cdot / \cdot r$ & $-1 / r \Lambda$ & $r \cdot I r$ \\
\hline س & $-\cdot|\lambda|$ & $-\cdot / \cdot r$ &.$- / \Delta F$ & $-\cdot / \cdot r$ & $-1 / \Delta \mid$ & $r \cdot 1 r$ \\
\hline$-.1 \cdot 9$ & $-\cdot \mid \Delta r$ & -.111 & $-\cdot / V 9$ & $-\cdot 119$ & $-1 / 9 V$ & $r \cdot r r$ \\
\hline$-\cdot 1 \cdot \wedge$ & $-\cdot / \Lambda$ & $-\cdot 1 \cdot V$ & $-\cdot 1 \Delta \Delta$ & -.119 & $-1 / 90$ & r.r \\
\hline$-\cdot / \cdot r$ & $-\cdot 19$ & $-\cdot / \cdot r$ & $-\cdot / \Delta \Delta$ &.$- / 1 f$ & r// & $r \cdot r q$ \\
\hline$-\cdot \cdot \cdot f$ & $-\cdot / V r$ & $-\cdot \cdot \cdot 1$ & $-\cdot / V \Delta$ & $-\cdot / \cdot r$ & $-1 / \Delta \varphi$ & $r \cdot r$. \\
\hline
\end{tabular}

قدر مطلق كشش قيمتى خودى تقاضا براى كل انرزى در فعاليت توليد انواع رنت و روغن جلا و يوششهاى مشابه (Tr.T) بيش از ساير فعاليتهاست. همجنين، حساسيت تقاضاى انرزى به تغييرات قيمت خود بيشتر از بقيه نهادههاست، در حالى كه اين كشش در فعاليت توليد مواد

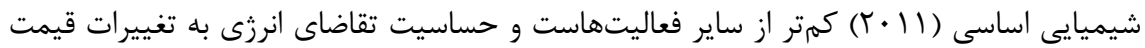

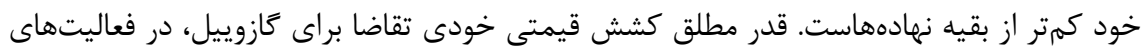

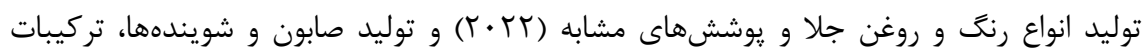

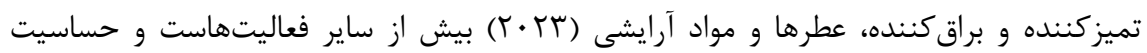

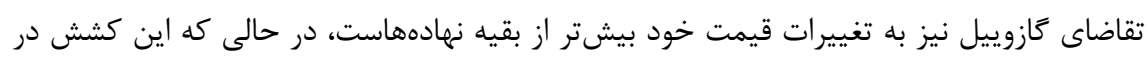

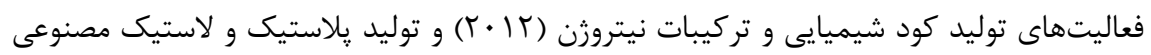

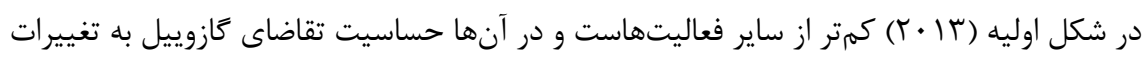
قيمت خود كمتر از بقيه نهادهاست. قدر مطلق كشش قيمتى خودى تقاضا براى كاز طبيعى در

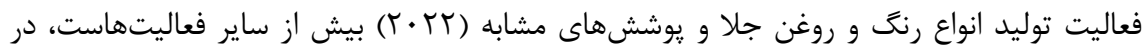

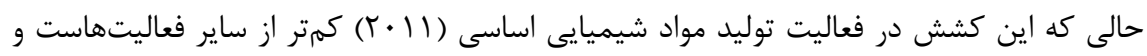
حساسيت تقاضاى كاز طبيعى به تغييرات قيمت خود كمتر از بقيه نهادههاست. قدر مطلق كششي

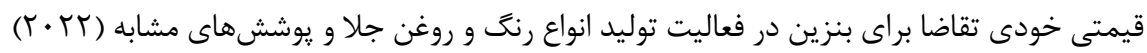

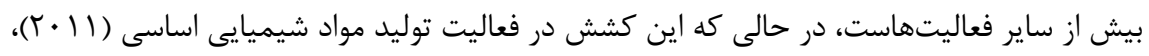

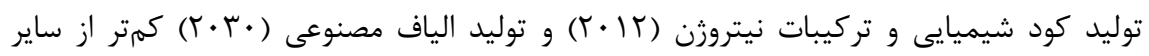
فعاليتهاست و حساسيت تقاضاى بنزين به تغييرات قيمت خود كمتر از بقيه نهادههاست. قدر مطلق 
كشش قيمتى خودى تقاضا براى برق در فعاليت توليد يّاستيك و لاستيك مصنوعى در شكل اوليه

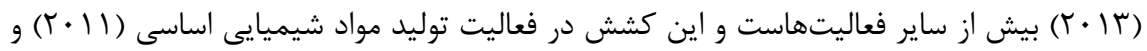
توليد كود شيميايى و تركيبات نيتروزن (T ( T) كمتر از ساير فعاليتهاست و حساسيت تقاضاى برق به تغييرات قيمت خود كمتر از بقيه نهادههاست. قدر مطلق كشش قيمتى خودى تقاضا براى ساير انرزى ها (َاز مايع، نفت كوره، و زغال سنگ)، در فعاليت توليد يُلاستيك و لاستيك مصنوعى در شكل

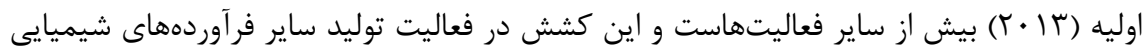
طبقهبندىنشده در جاى ديكر (9 · r) كمتر از ساير فعاليتهاست و حساسيت تقاضاى ساير انرزىها به تغييرات قيمت خود كمتر از بقيه نهادههاست.

\section{بحث و نتيجه كيرى}

هدف اين يزوهش تجزيلهوتحليل تابع هزينه و محاسبه انواع كششها در صنايع شيميايى ايران به

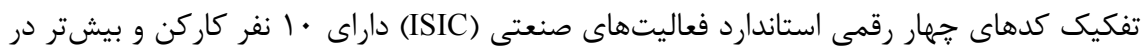

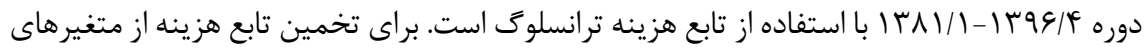
موجودى سرمايه، اشتغال، انرزى، و توليد استفاده شده، تابع هزينه صنايع شيميايى در هفت فعاليت

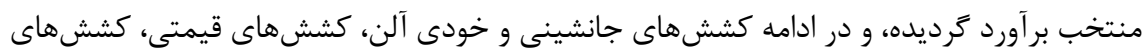
موريشيما، كشش انواع انرزى، و كشش بازدهى نسبت به مقياس محاسبه شده است. نتايج بر آورد تابع هزينه صنايع شيميايى نشان مى دهد در توليد صنايع كود شيميايى و تركيبات

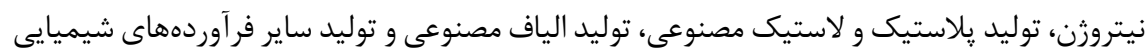
طبقلبندىنشده، با فرض ثبات ساير شرايط، تغييرات قيمت نهاده انرزى بيشتر لورئر از قيمت ساير نهادهها هزينههاى توليد را تحت تاثير قرار خواهد داد. در حالى كه در فعاليت توليد مواد شيميايى اساسى،

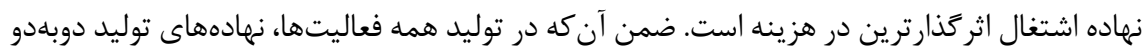

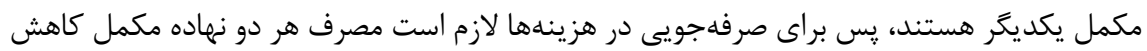
يابد. از سوى ديخر، در فعاليتهاى توليد انواع رنگ و روغن جلا و يوششهاى مشابه و توليد صابون، شويندهها، تركيبات تميزكننده و براق كننده، عطرها و مواد آرايشى اين قيمت نهاده سرمايه است كه

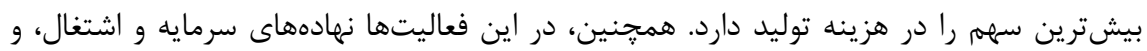

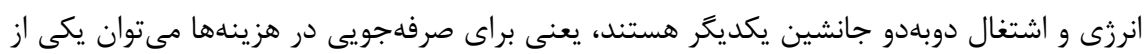
نهادهها را جايگزين ديخرى نمود. 
به علاوه، يزوهش حاضر نتايج برآورد كششهاى جانشينى جزئى متقاطع و خودى آلن، ميزان و جهت رابطه بين قيمت و تقاضاى نهادهها، و همجنين ميزان و جهت تاثير يذيرى تقاضاى يكى نهاده از قيمت نهاده ديكر را در فعاليتهاى مختلف نشان داده است. به عنوان يك نمونه ملموس، در فعاليت توليد صابون، شويندهها، تركيبات تميزكننده و براق كننده، عطرها و مواد آرايشى اثر افزايش قيمت نهاده كار (دستمزد) در تابع هزينه توليد مىتواند از طريق جايگزين نمودن نهاده موجودى سرمايه با

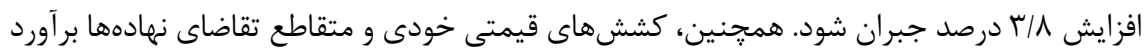
كرديده است. يافتهها حاكى از آن است كه در هر هفت فعاليت مورد بررسى، حساسيت تقاضاى

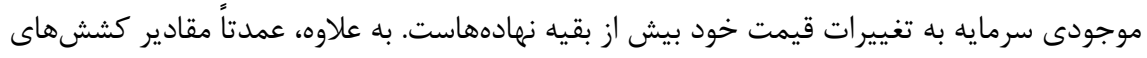

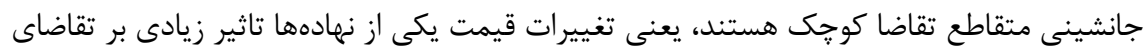
ديخرى نخواهد داشت. اين يزوهش همجنين كششهاى قيمتى خودى انواع انرزى به تفكيك (كل انرزى، كازوييل، كاز

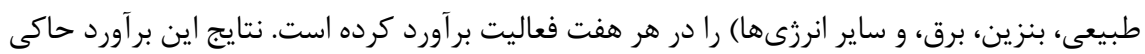
از آن است كه در فعاليتهاى توليد مواد شيميايى اساسى، توليد صنايع كود شيميايى و تركيبات نيتروزن، توليد انواع رنت و روغن جلا و يوششهاى مشابه و توليد الياف مصنوعى كشش قيمتى خودى كاز طبيعى بيش از ساير انواع انرزى است. اين در حالى است كه در فعاليتهاى توليد ساير

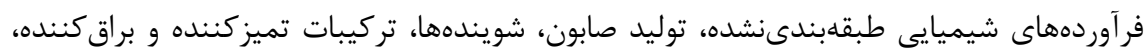

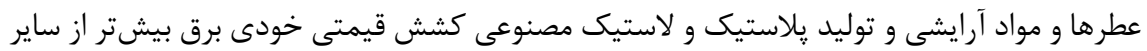
نهادههاست. همجنين، فعاليتهاى منتخب در اين يزووهش داراى بازدهى فزاينده نسبت به مقياس

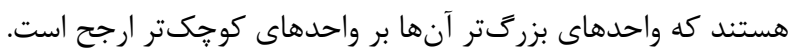

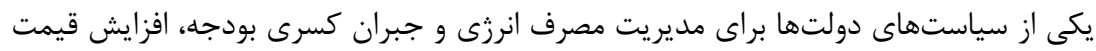
انرزى است. از طرفى، تغييرات قيمت انرزى به عنوان نهادهاى مهم در هزينه و عملكرد بسيارى از صنايع و نيز اثركذارترين نهاده در فعاليتهاى توليد صنايع كود شيميايى و تركيبات نيترورن

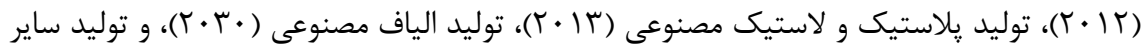

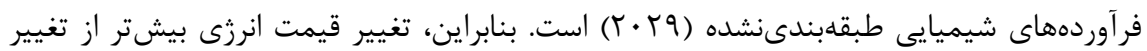

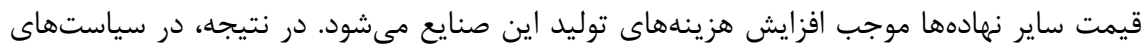
تغيير قيمت انرزى لازم است اين ملاحظات و برايند سياست مذكور و تبعات آن بر توليد اين صنايع لحاظ شود، سيس تصميم نهايى اتخاذ گردد. 


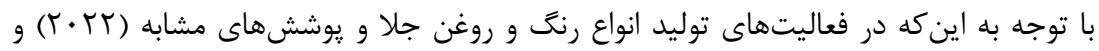

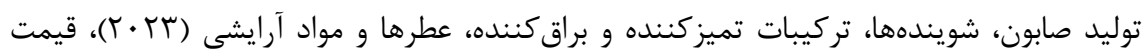

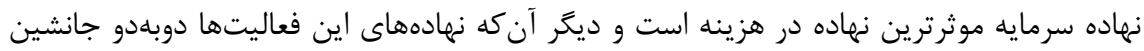
يكديكر هستند، در صورت تغيير قيمت يكى از نهادها براى صرفهجويى در هزينهها مىتوان نهاده ديگر را جايكزين نمود. تصميمَيران توليد مواد شيميايى اساسى (1) (1)، بايد مطلع باشند كه اشتغال، اثركذارترين نهاده در هزينه اين فعاليت است، يس در سياستهاى مرتبط با تعيين دستمزد يا تعديل نيروى كار،

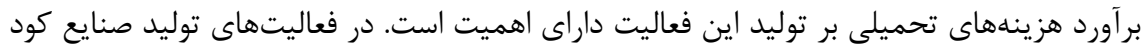

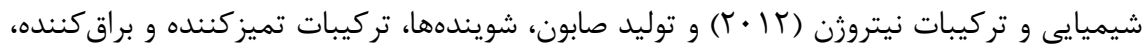
عطرها و مواد آرايشى (rr · r)، رابطه معكوس بين قيمت و مقدار تقاضاى موجودى سرمايه وجود ندارد، پس سياست تغيير قيمت نهاده سرمايه در اين فعاليتها تاثيرى بر ميزان تقاضاى سرمايه ندارد.

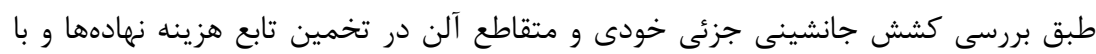

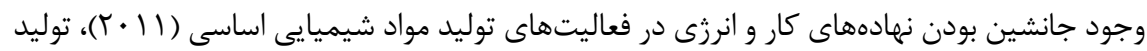

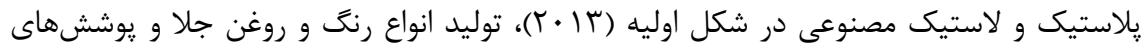

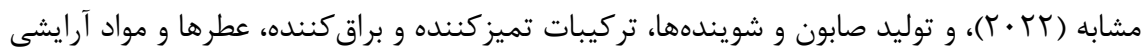

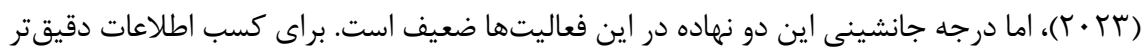

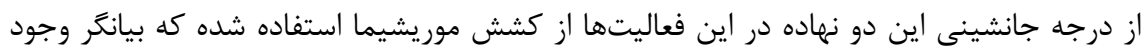
جانشينى قوى بين دو نهاده كار و انرزى در همه فعاليتهاى مذكور، بلاستثناى فعاليت توليد مواد

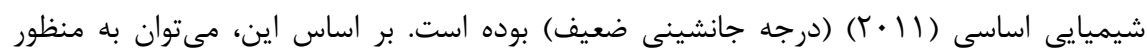

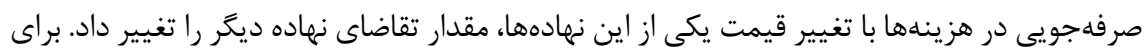
مثال، به منظور افزايش اشتغالزايى مىتوان قيمت نهاده انرزى را افزايش داد، كه به تبع آن افزايش

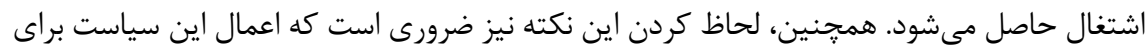

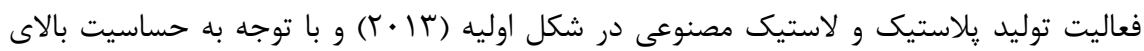
هزينههاى توليد اين فعاليت به تغيير قيمت انرزى نسبت به ساير نهادهها لازم است برايند سياست

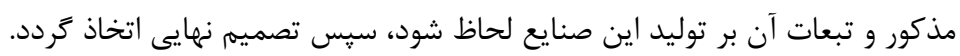

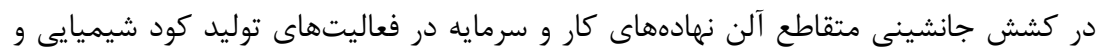

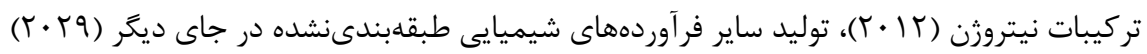


و توليد الياف مصنوعى (•r.r) جانشين هستند، اما در بررسى كشش موريشيما بهاستثناى فعاليت

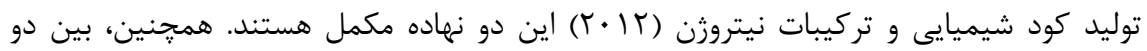

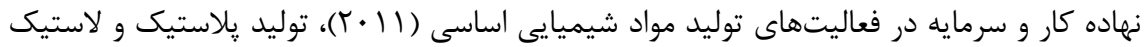

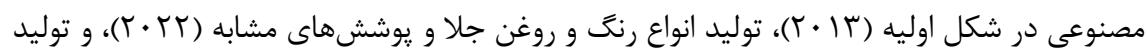

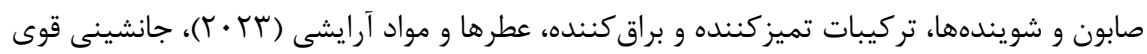

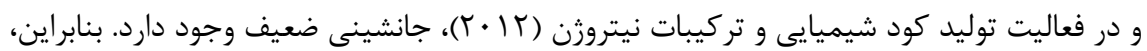

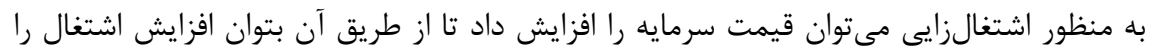

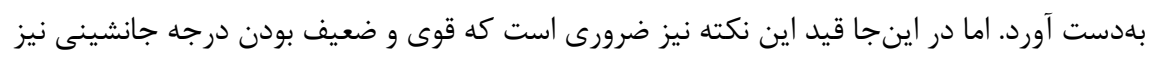
بايد مد نظر قرار كيرد و با توجه به قوى بودن درجه جانشينى اين دو نهاده در فعاليتهاى مذكور،

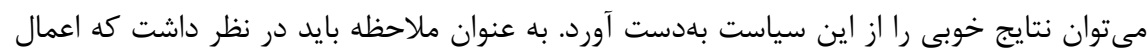
اين سياست، موجب عقبافتادگى فعاليتهاى مذكور در استفاده از فناورىهاى بلهروز نشود. همجنين، مطابق بررسى كشش قيمتى خودى و متقاطع تقاضاى نهادهها در فعاليتهاى صنايع شيميايى و با توجه به اينكه بيشتر مقادير كششهاى جانشينى متقاطع تقاضا كوجى هستنى، سياستهاى تغيير قيمت در اين نهادهها تغيير جندانى در تركيب هزينهاى فعاليتهاى مذكور نخواهد داشت. همجنين، تغيير قيمت يكى از نهادهها تاثير زيادى بر تقاضاى نهاده ديكر ندارد. با وجود اين كهن

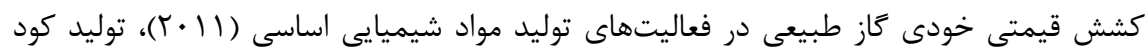

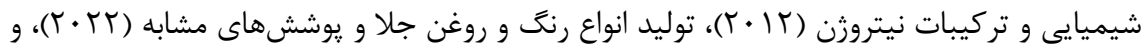
توليد صابون و شويندهها، تركيبات تميز كننده و براق كننده، عطرها و مواد آرايشى (Tr • r) در مقايسه با ساير انرزىها بيشتر است، اما بهطور كلى بى كشش است و سياست قيمتى كاز طبيعى اثر كمترى

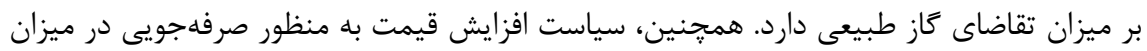
مصرف گاز طبيعى نيز نتايج قابلقبولى ارائه نخواهد داد. كشش قيمتى خودى برق در فعاليتهاى توليد پِلاستيك و لاستيك مصنوعى در شكل اوليه

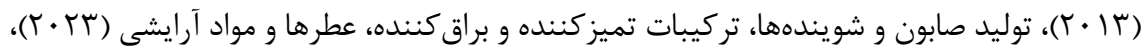

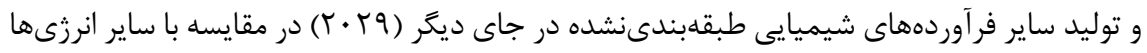
بيشتر است، اما بلطور كلى بى كشش است و سياست قيمتى برق اثر كمترى بر ميزان تقاضاى برق خواهد داشت. همجنين، سياست افزايش قيمت به منظور صرفهجويى در ميزان مصرف برق نيز نتايج 
در تمامى كدهاى مورد بررسى، تقاضاى هر دو انرزى بنزين و گازوييل نسبت به تغيير قيمت آنها بى كشش است و افزايش قيمت تاثيرى بر ميزان تقاضاى اين انرزىها در فعاليتهاى صنايع شيميايى مدريى و صرفهجويى در هزينها نخواهد داشت.

در خصوص سهم :زوهش حاضر مىتوان ادعا نمود اين يزوهش در مواردى جون دوره زمانى،

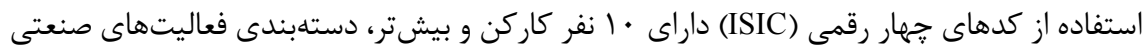
شبيه به هم در يك گروه، استفاده از متغير انرزى مصرفى در بخش صنعت به عنوان يكى از عوامل توليد، و استفاده از دادههاى فصلى بخش صنعت داراى تفاوت است كه مى توان كفت در موارد ذكرشده نسبت به مطالعات كذشته در ايران سهمى متفاوت در ادبيات تجربى دارد.

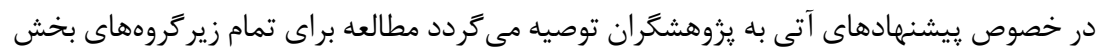
صنعت صورت يذيرد و نتايج زيربخشهاى مختلف با يكديكر مقايسه گردد. عمدهترين محدوديت اين

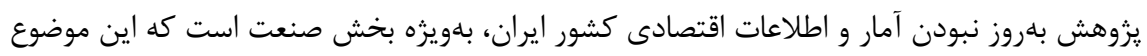

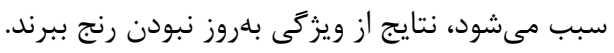

با توجه به آنكه يزوهش حاضر بركرفته از طرح يزوهشى است كه در موسسه مطالعات و

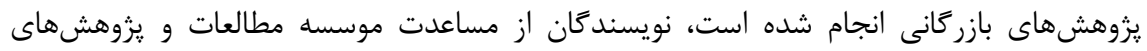

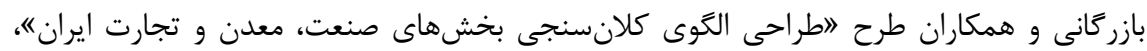
داوران، و ويراستار محترم نشريه علمى "برنامهريزى و بودجه" (مازيار خابك) تشكر و قدردانى مى كنند.

Alvarez, M. A., \& Lawrence, N. D. (2008). Sparse Convolved Gaussian Processes for Multi-Output Regression. Paper Presented at the NIPS.

Asadi Mehmandosti, E., Bazzazan, F., \& Mousavi, M. H. (2018). Calculating Total Factor Productivity and Substitution Elasticities in the Manufacturing Sector in Iran. Iranian Journal of Economic Research, 23(74), 1-32. https://dx.doi.org/10.22054/ijer.2018.8824 Asgari, M. (2019). Technical Efficiency in Iran's Industry Sector: A Stochastic Frontier 
Analysis (SFA) Approach. The Journal of Planning and Budgeting, 24(3), 61-85. http://jpbud.ir/article-1-1876-fa.html

Berndt, E. R., \& Christensen, L. R. (1973). The Translog Function and the Substitution of Equipment, Structures, and Labor in US Manufacturing 1929-1968. Journal of Econometrics, 1(1), 81-113. https://doi.org/10.1016/0304-4076(73)90007-9

Bölük, G., \& Koç, A. A. (2010). Electricity Demand of Manufacturing Sector in Turkey: A Translog Cost Approach. Energy Economics, 32(3), 609-615. https://doi.org/10.1016/j.eneco.2010.01.007

Breusch, T. S., \& Pagan, A. R. (1980). The Lagrange Multiplier Test and Its Applications to Model Specification in Econometrics. The Review of Economic Studies, 47(1), 239-253. https://doi.org/10.2307/2297111

Christensen, L. R., Jorgenson, D. W., \& Lau, L. J. (1973). Transcendental Logarithmic Production Frontiers. The Review of Economics and Statistics, 55(1), 28-45. https://doi.org/10.2307/1927992

Deininger, S. M., Mohler, L., \& Mueller, D. (2018). Factor Substitution in Swiss Manufacturing: Empirical Evidence Using Micro Panel Data. Swiss Journal of Economics and Statistics, 154(1), 1-15. https://doi.org/10.1186/s41937-017-0016-5

Diewert, W. E. (1971). An Application of the Shephard Duality Theorem: A Generalized Leontief Production Function. Journal of Political Economy, 79(3), 481-507. https://doi.org/10.1086/259764

Feng, G., \& Serletis, A. (2008). Productivity Trends in US Manufacturing: Evidence from the NQ and AIM Cost Functions. Journal of Econometrics, 142(1), 281-311. https://doi.org/10.1016/j.jeconom.2007.06.002

Gallant, A. R. (1981). On the Bias in Flexible Functional Forms and an Essentially Unbiased Form: The Fourier Flexible Form. Journal of Econometrics, 15(2), 211-245. https://doi.org/10.1016/0304-4076(81)90115-9

Gervais, J.-P., Bonroy, O., \& Couture, S. (2006). Economies of Scale in the Canadian Food Processing Industry. Munich Personal RePEc Archive (MPRA) Paper, No. 64.

Guilkey, D. K., \& Lovell, C. K. (1980). On the Flexibility of the Translog Approximation. International Economic Review, 21(1), 137-147. https://doi.org/10.2307/2526244

Huang, B. (2001). Fertilizer Usage in Mainland China. Agricultural Policy and Agriculture.

Kaghazian, S., Naghdi, Y., \& Sepehri, Y. (2016). Surveying the Influence of Inputs on the Cost Function of Refah Bank and the Possibility of Inputs Substitution. Iranian Journal of Trade Studies, 20(79), 155-176. http://pajooheshnameh.itsr.ir/article_22209.html

Kuroda, Y. (1987). The Production Structure and Demand for Labor in Postwar Japanese Agriculture, 1952-1982. American Journal of Agricultural Economics, 69(2), 328-337. https://doi.org/10.2307/1242283

Lin, B., \& Tian, P. (2017). Energy Conservation in China's Light Industry Sector: Evidence from Inter-Factor and Inter-Fuel Substitution. Journal of Cleaner Production, 152(1), 125-133. https://doi.org/10.1016/j.jclepro.2017.03.099

Lopez, R. E. (1980). The Structure of Production and the Derived Demand for Inputs in Canadian Agriculture. American Journal of Agricultural Economics, 62(1), 38-45. https://doi.org/10.2307/1239470

Lotfalipour, M. R., Falahi, M. A., \& Zohoorian, E. (2018). The Review of Substitution between 
Energy and Labor in Industry Sector of Iran (With Emphasis on Environmental Policy). Quarterly Energy Economics Review, 13(55), 39-68. http://iiesj.ir/article-1-839-fa.html

Morishima, M. (1967). A Few Suggestions on the Theory of Elasticity. Keizai Hyoron (Economic Review), 16(1), 144-150.

Moss, C. B., Erickson, K. W., Ball, V. E., \& Mishra, A. K. (2003). A Translog Cost Function Analysis of US Agriculture: A Dynamic Specification. Paper Prepared for Presentation at the American Agricultural Economics Association Annual Meeting, Montreal, Canada.

Ray, S. C. (1982). A Translog Cost Function Analysis of US Agriculture, 1939-1977. American Journal of Agricultural Economics, 64(3), 490-498. https://doi.org/10.2307/1240641

Shahbazi, M., \& Fadaee, M. (2017). The Relationship between Production Inputs and Energy Carriers in Iran's Manufacturing Sector. The Journal of Planning and Budgeting, 21(4), 134-171. http://jpbud.ir/article-1-1501-en.html

Stern, D. I. (1994). Accuracy of the Translog Function. Applied Economics Letters, 1(10), 172-174. https://doi.org/10.1080/135048594357943

Varian, H. (1992). Microeconomic Analysis: WW Norton and Company.

Wales, T. J. (1977). On the Flexibility of Flexible Functional Forms: An Empirical Approach. Journal of Econometrics, 5(2), 183-193. https://doi.org/10.1016/0304-4076(77)90023-9

White, H. (1980). Using Least Squares to Approximate Unknown Regression Functions. International Economic Review, 21(1), 149-170. https://doi.org/10.2307/2526245

$$
\begin{aligned}
& \text { ب) فارسى }
\end{aligned}
$$

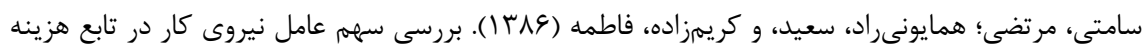

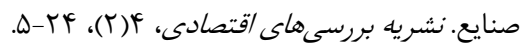

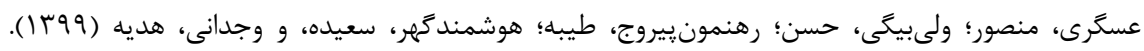

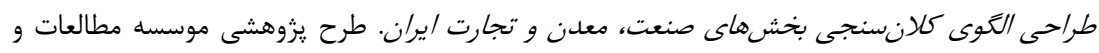

$$
\begin{aligned}
& \text { يزوهش هاى بازر كانى. }
\end{aligned}
$$

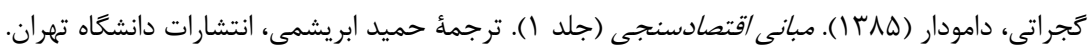

